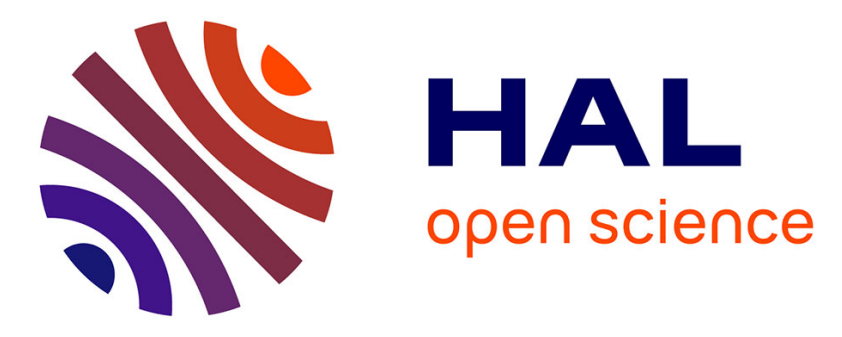

\title{
Real-time assessment of wintertime organic aerosol characteristics and sources at a suburban site in northern France
}

Roger Roig Rodelas, Abhishek Chakraborty, Esperanza Perdrix, Emmanuel Tison, Véronique Riffault

\section{To cite this version:}

Roger Roig Rodelas, Abhishek Chakraborty, Esperanza Perdrix, Emmanuel Tison, Véronique Riffault. Real-time assessment of wintertime organic aerosol characteristics and sources at a suburban site in northern France. Atmospheric Environment, 2019, 203, pp.48-61. 10.1016/j.atmosenv.2019.01.035 . hal-02567664

\section{HAL Id: hal-02567664 \\ https://hal.science/hal-02567664}

Submitted on 21 Oct 2021

HAL is a multi-disciplinary open access archive for the deposit and dissemination of scientific research documents, whether they are published or not. The documents may come from teaching and research institutions in France or abroad, or from public or private research centers.
L'archive ouverte pluridisciplinaire HAL, est destinée au dépôt et à la diffusion de documents scientifiques de niveau recherche, publiés ou non, émanant des établissements d'enseignement et de recherche français ou étrangers, des laboratoires publics ou privés.

\section{()ㅜ(1)}

Distributed under a Creative Commons Attribution - NonCommercial| 4.0 International 
1

\section{Real-time assessment of wintertime organic aerosol characteristics and sources at a suburban site in northern France}

\author{
Roger Roig Rodelas ${ }^{1}$, Abhishek Chakraborty ${ }^{1}$, Esperanza Perdrix ${ }^{1}$, Emmanuel Tison ${ }^{1}$, Véronique \\ Riffault ${ }^{1, *}$ \\ ${ }^{1}$ IMT Lille Douai, Univ. Lille, SAGE - Département Sciences de l'Atmosphère et Génie de \\ l'Environnement, F-59000 Lille, France \\ *Corresponding author: Véronique Riffault (veronique.riffault@imt-lille-douai.fr)
}


A high-resolution time-of-flight aerosol mass spectrometer (HR-ToF-AMS) was deployed during wintertime (5 February to 15 March 2016) at a suburban site in Douai, northern France, in order to investigate the characteristics and sources of the organic matter $(\mathrm{OM})$. The campaign average concentration of non-refractory submicron particulate matter $\left(\mathrm{NR}-\mathrm{PM}_{1}\right)$ was $11.1 \pm 9.3 \mu \mathrm{g} \mathrm{m}^{-3}$, and composed of $38 \% \mathrm{OM}, 36 \%$ nitrate, $16 \%$ ammonium and $9 \%$ sulfate. The average values for the OM:OC, O:C and $\mathrm{H}: \mathrm{C}$ ratios were $1.60 \pm 0.15,0.32 \pm 0.11$ and $1.55 \pm 0.14$, respectively, indicating a moderate level of aerosol oxidation. The positive matrix factorization (PMF) source apportionment method was applied to the high-resolution organic aerosol (OA) mass spectra, resulting in four factors: a hydrocarbon-like (HOA) factor; one associated with oxidized biomass burning (oBBOA); and two oxygenated factors (OOA) denoted as less oxidized (LO-OOA) and more oxidized (MO-OOA), with average contributions to OA of $20 \%, 28 \%, 17 \%$ and $35 \%$, respectively. The oBBOA factor was found to be mainly local as shown by non-parametric wind regression (NWR) analysis, and to correlate well with relative humidity (RH), suggesting fast aqueous processing of locally emitted primary biomass burning emissions. During most part of the campaign, the sampling site was affected by different air masses. However, during the last period of the campaign (5-16 March 2016) the site was heavily impacted by air masses from Eastern Europe which were rich in secondary inorganic and organic aerosols. The $\mathrm{H}: \mathrm{C}$ versus O:C (Van Krevelen, VK) diagram highlighted that the aerosol followed an oxidation process throughout the whole campaign, with an average slope of -1.05. The impact of continental air masses towards the end of the campaign confined the aerosol towards a narrower space in the VK diagram, suggesting a homogenization of the different aerosol sources due to OA ageing during transport. Several nocturnal NPF (new particle formation)-like events were observed and associated to the fast processing of BBOA emissions and the formation of ammonium nitrate.

Keywords: AMS; organic aerosols; source apportionment; aqueous processing 


\section{Introduction}

Atmospheric aerosols have gained attention worldwide due to their various impacts on human health (Kelly and Fussell, 2012), climate, visibility and ecosystems (Hallquist et al., 2009; IPCC, 2013; Watson, 2002). In the year 2016 only, air pollution was responsible for 7 million deaths worldwide (WHO, 2018), mostly due to inhalation of fine particulate matter $\left(\mathrm{PM}_{2.5}\right)$. In Europe, the premature mortality associated to air pollution is also alarmingly high, with estimations for the year 2016 ranging from 208,000 to 348,000 for high-income and low- to middle-income countries, respectively (WHO, 2018). The region of northern France is also affected by high levels of $\mathrm{PM}_{2.5}$, particularly during winter and spring (Atmo Nord-Pas-de-Calais, 2014). These high levels are mainly attributed to its location amidst various emission source areas including an extensive highway network, a high urban density, and the proximity to several European capitals (London, Paris, and Brussels) as well as a significant influence of industry and agriculture.

While the elemental and inorganic fractions of ambient aerosols are rather well understood, the characterization of the organic matter (OM) still remains a challenge due to their complex nature, associated to numerous emission sources and atmospheric transformations (Hallquist et al., 2009; Jimenez et al., 2009). OM can represent from 20 to $90 \%$ of the total submicron aerosol ( $\mathrm{PM}_{1}$ ) mass (Jimenez et al., 2009), and hence understanding its sources and transformation processes is essential in order to develop effective mitigation policies. OM, also called organic aerosol (OA), is typically divided into primary (POA) and secondary organic aerosols (SOA). POA are directly emitted to the atmosphere by a variety of sources comprising anthropogenic ones such as traffic, industrial activities, and residential biomass combustion; and natural ones like sea spray, volcanic emissions, forest fires, etc. (Hallquist et al., 2009; Mohr et al., 2009). SOA are formed in the atmosphere through several physicochemical processes of gas phase VOCs (volatile organic compounds) or POA (Kanakidou et al., 2005).

Different techniques have been developed in the past decades to analyze the nature and composition of OA. Most of these techniques work in offline mode; post analysis of the collected samples. These techniques can provide more exhaustive information on the nature and characteristics of individual organic species, but they require large amounts of samples which generally result in a low time resolution (of several hours). Since most of the atmospheric reactions occur at a time scale of few tens of minutes, these offline techniques often fail to elucidate the underlying atmospheric processes (Hallquist et al., 2009). On the contrary, online techniques provide less exhaustive information on individual chemical species but can characterize bulk OA with a very high time resolution (of seconds to minutes). Among the available online techniques, aerosol mass spectrometry (AMS) has become quite popular, since it allows the measurement of the chemical composition and mass loading as a function of the particle size in the submicron range (Canagaratna et al., 2007).

Besides, the combination of AMS data with source apportionment techniques, mainly positive matrix factorization (PMF) and multi-linear engine (ME-2), has allowed for the study of the OA sources and characteristics (Ulbrich et al., 2009). Several AMS-PMF studies have shown 
that OA can typically be separated into secondary or oxygenated OA (OOA), and several primary OA types like hydrocarbon-like OA (HOA), biomass burning OA (BBOA) and cooking OA (COA), depending on the site location and sampling season (Bozzetti et al., 2017; Crippa et al., 2014; Florou et al., 2017; Lanz et al., 2010; Mohr et al., 2012; Poulain et al., 2011; Saarikoski et al., 2012; Timonen et al., 2013). In France, a few studies have focused on the OA sources and characteristics using real-time measurements in Paris (Crippa et al., 2013), Marseille (Bozzetti et al., 2017), and in the north of France in Douai and Dunkirk which showed that winter OA was moderately oxidized and mostly composed of OOA, while significant contributions of BBOA, HOA and sulfur-containing OA (SCOA) were also found (Crenn et al., 2017a, 2017b).

In this context, this intensive campaign using a high-resolution time-of-flight aerosol mass spectrometer (HR-ToF-AMS) and carried out in winter 2016 at a suburban site in Douai was deployed with the aim of complementing ongoing long-term measurements with a Monitor for Gases and AeRosols in ambient Air (MARGA) and other collocated instrumentation which focused on the source apportionment of the $\mathrm{PM}_{2.5}$ inorganic aerosol with an hourly resolution (Roig Rodelas et al., in press). This work focuses on the characterization of the chemical composition of NR-PM 1 and of the sources of OA obtained by PMF analysis during winter in Douai. In addition, the influence of meteorological characteristics and long-range transport on the characteristics of NR-PM $\mathrm{PM}_{1}$ is also evaluated.

\section{Materials and methods}

\subsection{Measurement site}

Observations of the chemical composition of atmospheric aerosols were carried out from 5 February to 16 March 2016 in Douai, northern France, at a suburban location outside the city center (Figure S1) which is considered as representative of the background pollution of the area $\left(50^{\circ} 23^{\prime} 03^{\prime}\right.$ 'N , 3 $3^{\circ} 05^{\prime} 08^{\prime}$ ' $\mathrm{E}$, and $20 \mathrm{~m}$ above sea level). The city of Douai is located in a fairly flat land and is close (about 25-30 km south) to the European Metropolis of Lille. Lille is the second most densely populated metropolis in France, after that of Paris, with about 1.2 million inhabitants and a population density of 1,832 inhab. $\mathrm{km}^{-2}$. The climate in northern France is classified as temperate oceanic, characterized by low seasonal thermal amplitudes, and regular precipitations along the year, with no dry season.

\subsection{Instrumentation}

The high resolution-time of flight-aerosol mass spectrometer (HR-ToF-AMS) (Aerodyne Research, USA), hereafter named AMS, was deployed in order to measure in real-time the chemical composition and concentrations of the non-refractory $\mathrm{PM}_{1}\left(\mathrm{NR}-\mathrm{PM}_{1}\right)$ (DeCarlo et al., 2006). The major species composing NR-PM 1 include $\mathrm{NO}_{3}, \mathrm{NH}_{4}, \mathrm{SO}_{4}, \mathrm{Cl}$ and organic aerosols (OA). Due to the principle of AMS data analysis, the non-refractory species are vaporized and ionized by electron impact $(70 \mathrm{eV})$. Hence, the names of these species as used throughout this 
article (i.e. without charges) correspond to the sum of all the $\mathrm{m} / \mathrm{z}$ fragments related to one given species in the fragmentation table (Allan et al., 2004). The AMS operates in two modes according to the trajectory of the ions: the low resolution but highly sensitive $\mathrm{V}$ mode and the high resolution but less sensitive $\mathrm{W}$ mode. In this study, the time resolution of the AMS was set to 5 minutes, with 3 minutes for mode $\mathrm{V}$ and 2 minutes for mode $\mathrm{W}$. Only the results for the V mode are shown, since the lower sensitivity of the $\mathrm{W}$ mode delivered a too low signal-to-noise ratio during most of the campaign.

The mass concentration measurement accuracy of AMS depends on collection efficiency (CE) and ionization efficiency (IE) values. The CE considers the effects of incomplete focusing of the particle beam and bouncing of some particles from the vaporizer (Drewnick et al., 2005). Typically, a default CE value of 0.5 is used (Middlebrook et al., 2012). However, it has been shown that the $\mathrm{CE}$ is dependent on particle phase, which is influenced by the relative humidity in the sampling line above $80 \%$, the acidity/neutralization of the sulfate, ammonium nitrate, and organic content (Middlebrook et al., 2012). In this work a Nafion dryer was used in order to reduce the relative humidity in the sampling line. In addition, a composition dependent CE (CDCE), which recalculates the concentrations of all the chemical species by taking into account the $\mathrm{NO}_{3}$ fraction of the aerosol, was applied to the AMS data as proposed previously by Middlebrook et al. (2012).

The IE is defined as the ratio between the number of ions detected and the molecules of the parent species (Jimenez, 2003), and is species specific. Its value is determined through calibrations. However, since it is not practical to perform individual calibrations for all compounds in ambient aerosol, a reference calibration is typically performed for nitrate, and the relative IE (RIE) of every species is obtained relative to that of nitrate (Alfarra et al., 2004). We carried out calibrations every two weeks in order to determine $\operatorname{IE}\left(\mathrm{NO}_{3}{ }^{-}\right)$and $\mathrm{RIE}\left(\mathrm{NH}_{4}{ }^{+}\right)$using aqueous solutions of $10^{-2} \mathrm{~mol} \mathrm{~L}^{-1} \mathrm{NH}_{4} \mathrm{NO}_{3}$ (Sigma Aldrich, 99.0\%). $\mathrm{NH}_{4} \mathrm{NO}_{3}$ particles were generated by an atomizer (TSI 3076) and then dried by passing through a silica gel drier (TSI 3062). A dilution system composed of a set of valves and a HEPA (High Efficiency Particle Air) filter was used in order to vary the particle concentration. In addition, an electrostatic classifier (TSI 3080) and a differential mobility analyzer (TSI 3081) allowed selecting the particles with an electrical mobility diameter of $300 \mathrm{~nm}$. Finally, the particles entered simultaneously a condensation particle counter (TSI, 3788) and the AMS. Additional calibrations were carried out using aqueous solutions of $10^{-2} \mathrm{~mol} \mathrm{~L}^{-1}$ of $\left(\mathrm{NH}_{4}\right)_{2} \mathrm{SO}_{4}$ (Sigma Aldrich, 99.0\%) and $\mathrm{NH}_{4} \mathrm{Cl}(\mathrm{Sigma}$ Aldrich, 99.5\%) in order to determine the $\mathrm{RIE}$ for $\mathrm{SO}_{4}$ and $\mathrm{Cl}$, respectively. The RIE values were determined to be 4.0, 1.1 and 1.6 for $\mathrm{NH}_{4}, \mathrm{SO}_{4}$ and $\mathrm{Cl}$, respectively.

The processing of the AMS unit mass resolution (UMR) and high resolution (HR) data has been carried out by using the modules SQUIRREL (SeQUential Igor data RetRiEvaL, version 1.60E) and PIKA (Peak Integration by Key Analysis, version 1.20E), respectively (D. Sueper, University of Colorado-Boulder, Boulder, CO, USA) for Igor Pro v. 6.37 (Wavemetrics, Inc. Portland, OR, USA).

A scanning mobility particle sizer SMPS Model 3936 (TSI) was also deployed in order to obtain the particle number size distribution (PNSD) between 10 and $1083 \mathrm{~nm}$ every $7 \mathrm{~min}$. 
Additionally, several other instruments were used as part of a longer campaign (Roig Rodelas et al., in press), whose data are used for comparison purposes and as external tracers to validate the PMF identified factors. These included a MARGA 1S (Metrohm Applikon B.V, Netherlands) (ten Brink et al., 2007) for the measurement of water-soluble ions $\left(\mathrm{NO}_{3}{ }^{-}, \mathrm{SO}_{4}{ }^{2-}\right.$, $\mathrm{NH}_{4}{ }^{+}, \mathrm{K}^{+}$) and precursor gases (HONO) with an hourly resolution, a doublewavelengthaethalometer AE42 (Magee Scientific, USA) for black carbon (BC) and Delta-C with a 5-min time resolution, a chemiluminescence analyzer NOx 2000G (Seres environment, France) for nitrogen oxides every 15 minutes and a BAM-1020 (Met One Instruments, USA) for the $\mathrm{PM}_{2.5}$ total mass concentration every hour. The Delta-C variable was determined as the difference of light absorption between 370 and $880 \mathrm{~nm}$, and represents the enhanced optical absorption of some specific OA compounds (Allen et al., 2004). It has previously been found to correlate with wood-burning markers such as levoglucosan and $\mathrm{K}^{+}$and therefore might be used as a tracer of wood combustion (Allen et al., 2004; Wang et al., 2012). Meteorological parameters including temperature, relative humidity $(\mathrm{RH})$, and pressure were acquired from a BAM-1020 and a TEOM-FDMS. The wind speed and direction, and precipitation were monitored on site with an anemometer. The mixing layer height (MLH) was obtained from the GDAS meteorological data (1 degree) on the NOAA website.

\subsection{Source apportionment of $\mathrm{OA}$}

The Positive Matrix Factorization (PMF) method (Paatero and Tapper, 1994) was applied to the $\mathrm{V}$ mode HR OA mass spectra $(\mathrm{m} / \mathrm{z}=12$ to $\mathrm{m} / \mathrm{z}=150)$ in order to investigate the different sources of OA using the PMF Evaluation Tool (PET) v. 3.00 integrated into Igor Pro (Paatero and Tapper, 1994; Ulbrich et al., 2009). PMF analysis was carried out as per the guidelines of Paatero and Tapper, 1994 and Ulbrich et al., 2009. Weak species, with a signal-to-noise ratio (SNR) below 2 were down-weighted by a factor of 2 . In addition, the errors of $\mathrm{CO}_{2}^{+}$as well as the four ions associated with it in the fragment table $\left(\mathrm{O}^{+}, \mathrm{HO}^{+}, \mathrm{H}_{2} \mathrm{O}^{+}, \mathrm{CO}^{+}\right)$were downweighted automatically using PET in order to prevent excessive weighting of the signal at $\mathrm{m} / \mathrm{z} 44$ (Allan et al., 2004; Ulbrich et al., 2009). No fragments (SNR < 0.2) were removed from the database. We examined PMF solutions between 2 and 8 factors. The selection of the most appropriate solution was made by taking into account several criteria such as the variation of the $\mathrm{Q} / \mathrm{Q}_{\exp }$ ratio, the physical meaningfulness of the mass spectra representing each factor, the time series and daily cycles, and the relationship with external variables.

\subsection{Geographical determination of sources}

In order to get insight into the geographical origins of the sources of OA, we combined the data obtained by the PMF analysis with the wind speed and direction and the backtrajectories. The wind speed and wind direction were used by applying the non-parametric wind regression (NWR), a hybrid source-receptor model which locates and quantifies local sources of 
hourly averaged atmospheric concentrations of a pollutant based on wind speed (u) and direction ( $\theta$ ) (Henry et al., 2009) following equation 1:

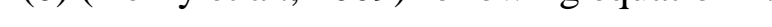

$$
E(C \mid \theta, u)=\frac{\sum_{i=1}^{N} K_{1}\left(\frac{\theta-W_{i}}{\sigma}\right) \cdot K_{2}\left(\frac{\mathrm{u}-U_{i}}{h}\right) \cdot c_{i}}{\sum_{i=1}^{N} K_{1}\left(\frac{\theta-W_{i}}{\sigma}\right) \cdot K_{2}\left(\frac{\mathrm{u}-U_{i}}{h}\right)}
$$

Eq. 1

where $E$ is the concentration estimate at a wind direction $\theta$ and wind speed $u ; W_{i}, U_{i}$ and $C_{i}$ the wind direction, speed and atmospheric concentrations, respectively, measured at $t_{i} ; \sigma$ and $h$ the smoothing factors (suggested by the software); and $K_{1}$ and $K_{2}$ are a Gaussian kernel function for wind direction $\theta$ and an Epanechnikov kernel function for wind speed $u$, respectively, used to get the smoothing (Henry et al., 2009).

The weighed concentrations obtained from Eq. 1 are then weighted by the wind frequency. Hence, an empirical joint probability density of wind speed and direction is calculated using the kernel density estimate, as shown in equation 2 :

$$
f(\theta, \mathrm{u})=\frac{1}{N \sigma h} \cdot \sum_{i=1}^{N} K_{1}\left(\frac{\theta-W_{i}}{\sigma}\right) K_{2}\left(\frac{u-U_{i}}{h}\right) \quad \text { Eq. } 2
$$

where $N$ is the total number of points.

The Potential Source Contribution Function (PSCF) is a statistical source-receptor model aiming at determining the geographical origins of high concentrations of air pollutants. It is based on the analysis of the residence times of air masses using air mass trajectories back in time. The main idea is that the longer an air mass stays over a pollution source, the higher the pollution brought by the air mass to the receptor site. Generally, the domain covered by the backtrajectories is meshed according to a regular grid. The PSCF model calculates the probability of having a pollutant source located inside each gridcell of the domain and responsible for pollutant concentrations measured at the receptor site above a given threshold, following equation 3 :

$$
P S C F=\frac{m_{i j}}{n_{i j}} \quad \text { Eq. } 3
$$

where $\mathrm{m}_{\mathrm{ij}}$ is the number of backtrajectory endpoints passing over the $\mathrm{ij}^{\text {th }}$ gridcell at latitude $i$ and longitude $j$ and associated to concentrations measured at the receptor site exceeding a specific threshold (in this case the $75^{\text {th }}$ percentile was used); and $n_{i j}$ the total number of trajectory endpoints passing over the $\mathrm{ij}^{\text {th }}$ gridcell.

A high value of the PSCF probability for the $\mathrm{ij}^{\text {th }}$ gridcell indicates a high probability that this gridcell corresponds to a source location. The backtrajectories used for PSCF analysis were calculated with HYSPLIT 4 (HYbrid Single-Particle Lagrangian Integrated Trajectory) for an arrival height of half of the planetary boundary layer, at 3-h intervals ( 8 trajectories per day at 0 , $3,6,9,12,15,18,21 \mathrm{UTC}$ ), and 72 hours back in time. Due to spatial resolution, PSCF was applied only to OA sources identified as regional by the NWR approach. In addition, a 
sigmoidal-type weighing function was applied when using PSCF in order to decrease the influence of grid cells with a few number of points.

The calculation of both NWR and PSCF was carried out using the Zefir v3.31 IGOR tool (Petit et al., 2017).

\subsection{Ventilation coefficient}

Additionally, we calculated the ventilation coefficient (i.e. the product of the mixing layer height and the wind speed; in $\mathrm{m}^{2} \mathrm{~s}^{-1}$ ) in order to evaluate whether the atmospheric conditions favor dispersion or accumulation of the pollutants at the sampling location (Goyal and Chalapati Rao, 2007). The dispersion condition in the site is considered as bad, moderate, good and excellent for ventilation coefficients between 0 and 2,000, 2,001 and 4,000, 4,001 and 6,000 and $>6,000 \mathrm{~m}^{2} \mathrm{~s}^{-1}$ respectively, according to the criteria of Eagleman (1991).

\section{Results and discussions}

\subsection{Overview of NR-PM}

The time series of the meteorological parameters, concentrations of the main components of NR-PM $M_{1}$ and $\mathrm{OA}$ elemental ratios are shown in Figure 1. The weather conditions during the campaign were mostly humid and cold, with average values for $\mathrm{RH}$ and $\mathrm{T}$ of $82 \pm 12 \%$ and $5.7 \pm 3.3^{\circ} \mathrm{C}$, respectively. Relatively low wind speeds were observed during the campaign, with an average of $1.6 \pm 1.2 \mathrm{~m} \mathrm{~s}^{-1}$, with calm winds from north and northeast alternating with strong winds from the southwest.

Moderate to high levels of NR-PM 1 were observed during the measurement campaign, with concentrations ranging from 0.23 to $50.9 \mu \mathrm{g} \mathrm{m}^{-3}$ and a campaign average concentration of $11.1 \pm 9.3 \mu \mathrm{g} \mathrm{m}^{-3}$. The NR-PM 1 composition was dominated by OA $\left(38.4 \% ; 4.2 \pm 3.1 \mu \mathrm{g} \mathrm{m}^{-3}\right)$ and $\mathrm{NO}_{3}\left(35.9 \% ; 4.0 \pm 4.3 \mu \mathrm{g} \mathrm{m}^{-3}\right)$ followed by $\mathrm{NH}_{4}\left(15.9 \% ; 1.8 \pm 1.8 \mu \mathrm{g} \mathrm{m}^{-3}\right)$ and $\mathrm{SO}_{4}(8.8 \%$; $\left.1.0 \pm 0.9 \mu \mathrm{g} \mathrm{m}^{-3}\right)$. The contribution of $\mathrm{Cl}$ was particularly low $\left(1.0 \%, 0.23 \mu \mathrm{g} \mathrm{m}^{-3}\right)$ throughout the campaign, and hence will not be further discussed. Previous studies in northern France carried

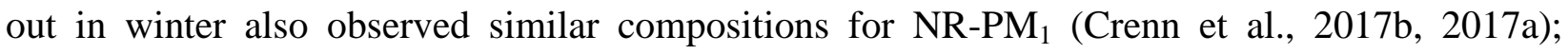
Zhang et al., in prep.). In addition, the major inorganic species in NR-PM 1 measured by the AMS $\left(\mathrm{NO}_{3}, \mathrm{NH}_{4}\right.$ and $\left.\mathrm{SO}_{4}\right)$ are well correlated $(\mathrm{r}>0.95)$ to those measured in $\mathrm{PM}_{2.5}$ by a MARGA $1 \mathrm{~S}$ (Roig Rodelas et al., in press). Some interesting changes were observed between the first part (5 February - 4 March 2016) and the second part (5-16 March 2016) of the campaign. During the second period, particularly high concentrations of NR-PM (up to $50 \mu \mathrm{g} \mathrm{m}^{-3}$ ) were observed. This was attributed to an impact of air masses originating from continental Europe and rich in secondary aerosols, as will be discussed in detail in section 3.4.

The daily profiles of the average concentrations and fractional contributions for the main species of NR-PM 1 are shown in Figure S2. Concentrations of $\mathrm{NO}_{3}$ and $\mathrm{NH}_{4}$ are higher during the nighttime, in accordance with the lower temperatures and higher $\mathrm{RH}$ favoring the partitioning of ammonium nitrate to the aerosol phase. On the other hand, the concentrations of sulfate do not 
show noticeable differences throughout the day, suggesting that it might be a result of transformation of regionally emitted $\mathrm{SO}_{2}$. In addition, the daytime production of $\mathrm{SO}_{4}$ might have been masked by the expansion of the boundary layer, and the nighttime lower boundary layer values might have caused higher $\mathrm{SO}_{4}$ thus the similar levels between daytime and nighttime. The daily cycle of OA shows two maxima, one in the early morning which could be linked to the vehicular emissions during the traffic rush hours, and one in the evening, which could be attributed to emissions from biomass burning, as will be further discussed in section 3.3. The difference in composition of the NR-PM 1 between daytime and nighttime was small, although the contribution of OA was higher through the night (41\% compared to $35 \%$ during daytime; Figure S2b), which could be attributed to a higher contribution of OA sources such as biomass burning during the nighttime, as will be discussed later.

The origin of the main components of NR-PM 1 was assessed with the use of polar plots, shown in Figure S3. We observed higher concentrations of $\mathrm{NO}_{3}$ and $\mathrm{NH}_{4}$ for low and moderate wind speeds from the NE sector, suggesting that a combination of local and regional sources could have contributed to the observed concentrations. High levels of $\mathrm{SO}_{4}$ are observed for low and moderate wind speeds in the NE sector. However, high concentrations of $\mathrm{SO}_{4}$ are also observed for other directions, implying that its origin could be rather regional, in agreement with its daily cycle. The polar plot for OA shows highest concentrations for very calm winds $\left(<1 \mathrm{~m} \mathrm{~s}^{-1}\right)$, pointing out significant local contributions. However, high concentrations of OA are also observed for moderate wind speeds from the NE and SE sectors, suggesting that regional sources are also important.

The acidity of the NR-PM 1 aerosol was evaluated by using the neutralization ratio (NR) (Figure S4). This is defined as the ratio between the observed ammonium and that required for the full neutralization of nitrate and sulfate. NR was close to 1 during most of the campaign, implying that there was always enough $\mathrm{NH}_{4}$ to neutralize $\mathrm{NO}_{3}$ and $\mathrm{SO}_{4}$.

\subsection{OA characteristics}

Calculation of OA elemental ratios indicates that $\mathrm{OA}$ was moderately oxidized during the campaign. The elemental ratios were calculated based on the calibration factors from Aiken et al. (2008). The average values for the OM:OC, O:C and $\mathrm{H}: \mathrm{C}$ ratios were $1.60 \pm 0.15,0.32 \pm 0.11$ and $1.55 \pm 0.14$, respectively. These values are consistent with previous wintertime observations at urban sites in France (Chakraborty et al., in prep.; Crenn et al., 2017b; Crippa et al., 2013).

The daily profiles of the elemental ratios are shown in Figure 2. The OM:OC and O:C ratios are found to be slightly higher during nighttime than daytime hours, which could be attributed to aqueous processing during nighttime due to very high $\mathrm{RH}$ levels and occurrence of some fog events. Higher or comparable nighttime $\mathrm{OM}: \mathrm{OC}$ and $\mathrm{O}: \mathrm{C}$ values have also been observed in previous studies (Brown et al., 2013; Florou et al., 2017; Hayes et al., 2013). High humidity and fog events can create a suitable environment for aqueous oxidation leading to higher O:C ratios. Li et al. (2013) and Chakraborty et al. (2015) reported oxidation of OA and possible changes in oxidation mechanism (functionalization vs fragmentation) from two moderate to highly polluted 
locations of Asia via AMS observations. Ge et al. (2012) and Dall'Osto et al. (2009) reported formation of organosulfates during fog events from Fresno, California, and London using AMS. Sullivan et al. (2016) detected aqueous SOA formation even in dark under high RH conditions. So, under foggy and high RH conditions night-time oxidation can also produce highly oxidized SOA. Stagnant conditions during winter nights, suggested by ventilation coefficient values lower than $1000 \mathrm{~m}^{2} \mathrm{~s}^{-1}$ (Eagleman, 1991) (Figure S5b), may have also allowed more time for the processing of local air masses. For instance, aqueous oxidation of primary biomass burning aerosols has already been reported (Gilardoni et al., 2016) and this will be discussed further in section 3.3. Relatively lower solar radiation (and thus less photochemical activity) may have led to the observed lower OA oxidation levels during daytime. The minima for OM:OC and O:C are found in the early morning (7-8 am UTC, that is to say 8-9 am local time) and afternoon (5-6 pm UTC), during the traffic rush hours. On the contrary, the $\mathrm{H}: \mathrm{C}$ ratio presents higher values during daytime, with maximum values during the traffic rush hours. In the literature, $\mathrm{H}$ : $\mathrm{C}$ usually shows a sharp decrease after reaching its maximum in the morning (Crippa et al., 2013; Docherty et al., 2011; Florou et al., 2017; Saarikoski et al., 2012). However, in this study H:C shows only a minor dip after its morning maximum, and remains steady until the afternoon traffic rush hours. This could be linked to the substantial contribution from some primary sources such as traffic outside rush hours (the road next to the sampling site is situated between an industrial zone and a commercial zone, implying that there is always some traffic of cars, trucks and buses).

The Van Krevelen plot (H:C vs O:C) can reveal some important information on the aging of the atmospheric OA (Heald et al., 2010). In Figure 3, OA elemental ratios are observed to move towards the lower right (higher $\mathrm{O}: \mathrm{C}$ and lower $\mathrm{H}: \mathrm{C}$ ) as the campaign proceeds. Some inferences can be drawn on OA aging based on the slope of this change of OA elemental ratios. In the same plot, reactions involving the addition/subtraction of several functional groups are illustrated with straight lines of different slope values. For instance, a slope of -2 is obtained when an aliphatic carbon group $\left(-\mathrm{CH}_{2}-\right)$ is replaced by a carbonyl group $<(-\mathrm{C}(=\mathrm{O})-)$, representing the loss of 2 hydrogens and the gain of 1 oxygen. The replacement of one hydrogen atom with an alcohol group (-OH-) results in a slope value of 0 . Lastly, a slope of -1 is obtained by the simultaneous addition of the carbonyl and alcohol groups (Heald et al., 2010). The data plotted in Figure 3 presented an average slope of -1.05 , which is in the range of values reported for other field campaigns (-0.8 to -1.1) (Hayes et al., 2013; Heald et al., 2010; Timonen et al., 2013). It is also observed that the elemental ratios of OA tend to be confined within a narrow area towards the end of the campaign, when aged air masses were arriving from continental Europe, as will be discussed in detail in section 3.4. This observed tendency implies that with the atmospheric aging due to transport, the chemical characteristics of bulk OA tend to be homogenized, as reported in several previous studies (Pan, 2015; Williams et al., 2007).

\subsection{Source apportionment of $\mathrm{OA}$}

The PMF analysis was applied to the high resolution mass spectra of OA by varying the number of factors from two to eight. The four factor solution was chosen based on the $\mathrm{Q} / \mathrm{Q}_{\exp }$ 
ratio, the chemical signatures of the different mass spectra, the time series and daily cycles, and the correlation with tracers and external variables. Reasoning behind this choice is presented in Table S1. The PMF diagnostics for the chosen solution are shown in Figure S6. The four factors were identified as hydrocarbon-like OA (HOA), oxidized biomass burning OA (oBBOA), more oxygenated oxidized OA (MO-OOA) and less oxygenated oxidized OA (LO-OOA).

When the number of factors was increased up to five, a HOA-COA mixed factor was obtained, which entailed the decrease of residuals at m/z 55 among others. The mass spectra, time series and daily profiles are shown in the supplementary material (Figure S7). However, the $\mathrm{Q} / \mathrm{Q}_{\text {exp }}$ barely decreased with respect to the four factor solution, and hence the four factor solution was finally chosen.

The mass spectra profiles and time series for each factor are shown in Figure $4 \mathrm{a}$ and $\mathrm{b}$, respectively. The higher contributions are observed for MO-OOA (33\%) and oBBOA (28\%), while LO-OOA (17\%) and HOA (20\%) constituted the remaining OA mass. The time series of each PMF factor and their correlation with tracer(s) are shown in Figure S8. In addition, in Table S2 the correlations between the PMF factors and the additionally available external variables are also presented.

As mentioned in section 2.4, linking the wind speed and direction data to the PMF factors can bring additional information on the sources of OA. Hence, in Figure 6 the NWR plots for each PMF factor are shown.

\subsubsection{HOA}

The HOA mass spectrum is dominated by the $C_{n} H_{2 n-1}^{+}$and $C_{n} H_{2 n+1}^{+}$ion series (Figure 4a), which are characteristic of OA mass spectra from vehicular exhaust emissions (Canagaratna et al., 2004). Accordingly, the HOA factor has the highest H:C ratio (2.03), and lowest OM:OC (1.36) and O:C (0.13) ratios among all the factors. The daily profile of HOA (Figure 5a) shows two prominent peaks in the morning and evening hours corresponding to higher traffic activities during the rush hours. HOA is observed to be strongly correlated with $\mathrm{m} / \mathrm{z} 57(\mathrm{r}=0.94$; Figure S8a), which is typically used as an internal tracer for HOA. Good correlations are also observed with external traffic tracers like $\mathrm{BC}(\mathrm{r}=0.70)$ and $\mathrm{NO}_{\mathrm{x}}(\mathrm{r}=0.72)$ (Figure S8a and Table S2). The obtained HOA mass spectrum is also compared to reference ambient spectra (Crippa et al., 2013; Docherty et al., 2011; Mohr et al., 2012; Struckmeier et al., 2016) obtained from the High Resolution AMS Spectral Database (http://cires1.colorado.edu/jimenez-group/HRAMSsd/) and excellent correlations are obtained $(r=0.89-0.98)$ (Figure S9). As shown in the NWR plot for HOA in Figure 6a, the highest concentrations are observed for very low wind speeds, suggesting that most of the HOA was locally emitted. In fact, a two-lane road is located adjacent to the sampling site and likely contributed notably to the observed HOA.

\subsection{2. oBBOA}


An oxidized BBOA factor was also retrieved by the PMF analysis. This factor is characterized by the presence of characteristic fragments of biomass burning at $\mathrm{m} / \mathrm{z} 60$ and 73 , associated to $\mathrm{C}_{2} \mathrm{H}_{4} \mathrm{O}_{2}{ }^{+}$and $\mathrm{C}_{3} \mathrm{H}_{5} \mathrm{O}_{2}{ }^{+}$, respectively (Figure 4a) (Alfarra et al., 2007). Accordingly, oBBOA is well correlated with its main tracer $\mathrm{m} / \mathrm{z} 60(\mathrm{r}=0.88$; Figure $\mathrm{S} 8 \mathrm{~b})$. In addition, good correlations are observed between oBBOA and Delta-C $(r=0.69$; Figure S8c and Table S2) and water-soluble $\mathrm{K}^{+}$from MARGA measurements $(\mathrm{r}=0.61)$ (Table $\left.\mathrm{S} 2\right)$. As explained in section 2.2, Delta-C can be used as a tracer of wood combustion.

oBBOA has a high degree of oxidation $(\mathrm{OM}: \mathrm{OC}=1.93$ and $\mathrm{O}: \mathrm{C}=0.58)$, with notable peaks in its mass spectrum at m/z $28\left(\mathrm{CO}^{+}\right), 29\left(\mathrm{CHO}^{+}\right)$and $44\left(\mathrm{CO}_{2}^{+}\right)$. The observation of a unique oxidized BBOA factor in OA PMF analysis is not common. Instead, most studies typically report a primary BBOA factor or two separate primary and oxidized BBOA factors. However, a recent study conducted in Houston, USA (Wallace et al., 2018), also reported the presence of a single oxidized BBOA factor (OM:OC and O:C of 2.03 and 0.65 , respectively).

One previous field study has provided evidence of aqueous processing of primary BBOA (Gilardoni et al., 2016), mainly through its correlation with RH. Sun et al. (2010) and Li et al. (2014) observed the rapid formation of oxidized compounds and enhancement in $\mathrm{O} / \mathrm{C}$ ratios via laboratory aqueous oxidation of phenolic compounds (phenol, syringol, guaiacol, etc.) originating from biomass burning activities, and identified similar signatures in ambient aerosols as well. So, both field and laboratory studies provide evidence that the aqueous oxidation of BBOA is possible under suitable atmospheric conditions. RH values during the present measurement campaign were particularly high, with an average of $82 \pm 12 \%$, which could promote aqueous processing of the OA. Indeed, when the correlation between the PMF factors and the RH (by bins) is evaluated (Figure 7), the concentration (and relative contribution) of oBBOA increases from $0.47 \mu \mathrm{g} \mathrm{m}^{-3}$ (12\% of OA) for $\mathrm{RH}<60 \%$ to $2.27 \mu \mathrm{g} \mathrm{m}^{-3}$ (31\%) for $\mathrm{RH}>95 \%$. This positive trend is observed between oBBOA and RH, while it is not observed for the other PMF factors. This, together with the NWR graph for oBBOA (Figure 6b) where higher concentrations are associated with low wind speeds, suggests that aqueous processing possibly led to the rapid oxidation of locally emitted biomass burning emissions forming oBBOA.

The daily profile of oBBOA (Figure 5) shows an increase of the concentration in the late afternoon and a maximum before midnight, after which the concentrations show a sharp decrease. This profile is in agreement with the time of biomass burning activities (in the evening), then lower MLH and higher RH values during the night, promoting the aqueous processing of fresh BBOA emissions.

\subsubsection{LO-OOA and MO-OOA}

Two OOA factors were obtained and denoted as LO-OOA and MO-OOA (Figure 4a). Even though their mass spectra are similar $(r=0.83)$, they are being considered as two separate factors since their degree of oxidation and time series are different $(r=0.62$; Figure $4 \mathrm{~b})$. The mass spectra of both factors are characterized by major peaks at $\mathrm{m} / \mathrm{z} 28$ and 44 , attributed to $\mathrm{CO}^{+}$and $\mathrm{CO}_{2}{ }^{+}$, respectively. However, the MO-OOA also includes a peak at m/z 29 associated to $\mathrm{CHO}^{+}$, 
whereas the LO-OOA does not and instead presents small contributions from alkyl fragments at $\mathrm{m} / \mathrm{z} 29$ and 64, attributed to $\mathrm{C}_{2} \mathrm{H}_{5}{ }^{+}$and $\mathrm{C}_{5} \mathrm{H}_{4}{ }^{+}$, respectively. Therefore, the MO-OOA factor presents higher $\mathrm{OM}: \mathrm{OC}$ and $\mathrm{O}: \mathrm{C}$ ratios (2.41 and 0.95 , respectively) in comparison to the LOOOA factor (2.00 and 0.61). However, both factors have very similar $\mathrm{H}: \mathrm{C}$ values (around 1.5) suggesting there was no evolution of the LO-OOA towards the MO-OOA, but rather that each OOA factor has a different origin and/or has been processed over a different timescale. While both factors showed a high correlation with $\mathrm{NO}_{3}(\mathrm{r}=0.79$ and 0.86 for MO-OOA and LO-OOA, respectively), the LO-OOA factor correlated better with $\mathrm{SO}_{4}(\mathrm{r}=0.84)$ than MO-OOA $(\mathrm{r}=0.59)$. This suggests that the LO-OOA could have a more regional origin. Even though the majority of AMS studies have reported correlations between sulfate and MO-OOA higher than with nitrate, there are a few exceptions. For instance, in China, Zhou et al. (2018) reported a poor correlation between MO-OOA and sulfate and concluded that both were being produced by aqueous oxidation. In addition, in more humid and colder conditions (similar to our sampling period), nitrate can stay longer in the particulate phase due to relatively lower evaporative loss, so it can be transported over longer distances just as sulfate (Seinfeld and Pandis, 2006; Zhou et al., 2018). $\mathrm{Xu}$ et al. (2016) reported higher MO-OOA vs. nitrate correlation than with sulfate, while LOOOA correlated well with both sulfate and nitrate. They attributed this finding to the fact that the nitrate formation was primarily occurring via photochemistry owing to lower temperature and humid conditions. In this study, a similar phenomenon has been observed, so most likely MOOOA and nitrate were both produced via photochemistry and showed good correlation, while LO-OOA, which has some significant regional contribution, correlates better with sulfate.

The time series of the MO-OOA factor shows similar concentrations throughout the whole campaign (Figure 4b). However, the LO-OOA factor presented low concentrations during most of the time except in the last period, where its contribution showed a remarkable increase (Figure 4b) due to the impact of air masses from continental Europe, as will be further discussed in section 3.4. The daily profiles of both factors showed a similar cycle, with smaller concentrations in the daytime (Figure 5a). For MO-OOA, the concentrations are observed to be steady during the night and early morning, but showed a decrease until the evening, and then started to increase again. For LO-OOA, the observed daily profile showed a similar but less pronounced trend. Concentrations of oxygenated factors are expected to be usually observed in the daytime, particularly in the afternoon, due to higher solar radiation which promotes photochemistry leading to the formation of secondary organic aerosols. However, in this study, the concentrations of OOA factors have decreased over the day (Figure 5a). This could be attributed to the strong dilution effect of the mixing layer, the values of which are higher in the afternoon (Figure S5a). Besides, although their concentrations are going down, their contributions to total OA are increasing (Figure 5b) indicating that OOA is produced but somewhat masked by the enhanced ML heights.

The NWR plots for the MO-OOA and LO-OOA factors show higher concentrations for lowto-moderate wind speeds from the NE sector (Figure 6c-d). This suggests that the origin of both factors is rather regional. The PSCF plots show that higher probabilities are observed for air masses from Belgium and Germany (Figure S10). 


\subsection{Impact of meteorological parameters and long range transport on NR-PM characteristics}

The entire campaign was further divided into two different periods based on mass loadings and meteorological conditions to gain further insights about the impact of meteorology and long range transport on aerosol characteristics. Period I (5 February to 4 March 2016) was

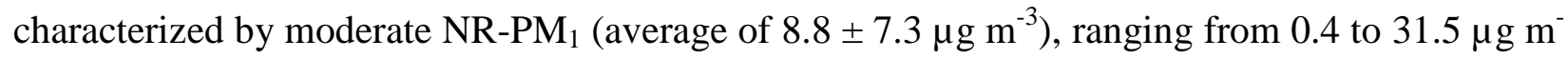
3 . On the other hand, period II (5 to 16 March 2016) showed high concentrations of NR-PM (average of $17.2 \pm 10.9 \mu \mathrm{g} \mathrm{m}^{-3}$ ) with values up to $50 \mu \mathrm{g} \mathrm{m}^{-3}$. The average temperatures and $\mathrm{RH}$ values were similar between both periods. However, period II was associated with anticyclonic conditions, with atmospheric pressure values higher than $1020 \mathrm{hPa}$, no precipitations $(4 \mathrm{~mm}$ in comparison to $73 \mathrm{~mm}$ for period I) and calm winds from the $\mathrm{N}$ and NE. In addition, during period II significantly lower values were observed for the mixing layer height during the nighttime (Figure S5a), which could favor the accumulation of pollutants. The ventilation coefficient (Figure S5b) also shows a similar trend, with lower nighttime values in period II $\left(<500 \mathrm{~m}^{2} \mathrm{~s}^{-1}\right)$ which indicate adverse conditions for the dispersion of pollutants (Eagleman, 1991). The backtrajectory density maps for each period (Figure S11) show that during period I higher probabilities of occurrence are observed for air masses from the north of France, suggesting that there is a higher influence from local areas. On the contrary, in period II high probabilities are observed for Belgium, Germany and Western Poland. Overall, this combination of factors contributed to the long-range transport of $\mathrm{NR}-\mathrm{PM}_{1}$ and its accumulation over the region of northern France.

The composition of the NR-PM 1 was also significantly different between both periods (Figure 8). In period I, the NR-PM 1 was dominated by OA, with an average of $43 \%$, while the inorganic ions constituted the rest of the mass, with $33 \% \mathrm{NO}_{3}, 15 \% \mathrm{NH}_{4}, 8 \% \mathrm{SO}_{4}$ and $1 \% \mathrm{Cl}$. In period II the OA contribution decreased to $32 \%$, and the percentage of the inorganic ions increases notably, particularly of $\mathrm{NO}_{3}$ to $39 \%$, but also of $\mathrm{NH}_{4}(18 \%)$ and $\mathrm{SO}_{4} \quad(10 \%)$. This suggests that during period I, local sources contributed more significantly to OA, while during period II the long-range transported air masses led to an increase of the levels of the inorganic aerosols.

While the total OA mass in period II was not significantly higher in comparison to period I (as opposed to the inorganic part of the aerosol), we observed significant differences in its composition (Figure 8). On the one hand, in period I the OA was dominated by local sources $(59 \%)$ with average contributions of $33 \%$ for oBBOA and $23 \%$ for HOA. Among the rather regional OA factors, MO-OOA clearly dominates (35\%) over LO-OOA (9\%) (Figure 8). This confirms that period I was mainly influenced by local sources.

In addition, what seems to be a nocturnal new particle formation ("NPF-like") event was distinguished in period I, and will be discussed in the next section. On the other hand, in period II the total contribution from local OA decreased significantly to $32 \%$, with average contributions 
of $18 \%$ for oBBOA, and $14 \%$ for HOA. The lower contribution of oBBOA during period II (i.e. under the influence of transported air masses from continental Europe) proves that primary biomass burning emissions are locally processed. The contribution of the regional factors increased up to $68 \%$ during period II. However, though the contribution of the MO-OOA factor is similar to that of period I (33\%), the contribution of LO-OOA sharply increased to $34 \%$. Therefore, it seems that the increase in LO-OOA in period II could be attributed to the impact of aged air masses transported from continental Europe.

Despite a significantly different composition of OA between both periods, the elemental ratios were rather similar. This could be attributed to a compensation of these ratios between the different OA factors (i.e. lower oBBOA and higher LO-OOA during period II).

\subsection{Nocturnal NPF-like event}

During the period where the SMPS was deployed, several nocturnal NPF-like events were detected, presenting a characteristic banana shape (Heintzenberg et al., 2007). This type of event corresponds to the growth of previously formed nanometer-sized particles. It may be characterized based on the apparent growth rate $g\left(t, D_{p}\right)$ of particles calculated from Eq. 4 :

$$
g\left(t, D_{p}\right)=\frac{\Delta D_{p}}{\Delta t}
$$

where $\Delta D_{p}$ is the geometric mean diameter of the particles $(\mathrm{nm})$ between the beginning and the end of the event and $\Delta \mathrm{t}$ is the duration of the event $(\mathrm{h})$.

In total, four significant NPF-like events were identified, all of them during nighttime. A summary on the characteristics of each event is given in Table 1 together with information on other NPF or NPF-like events observed in urban environments. The initial growth rates of these events were similar (ranging between 5.1 and $6.4 \mathrm{~nm} \mathrm{~h}^{-1}$ ), and well within the range of 0.25-39 $\mathrm{nm} \mathrm{h}^{-1}$ observed for other NPF events (Cheung et al., 2011; Fiedler et al., 2005; Hamed et al., 2007; Iida et al., 2008; Man et al., 2015; Salimi et al., 2017; Stolzenburg et al., 2005; Wu et al., 2007).

In this article, the results for the most representative event, which occurred from 15 to 16 February 2016, are presented. The event took place under anticyclonic conditions, with clear sky, calm winds, low temperatures and high RH values. Additionally, the ambient concentrations of $\mathrm{PM}_{2.5}$ in the previous hours of the NPF-like event were particularly low due to the occurrence of precipitations and marine air masses with little anthropogenic influence impacting the site. This low level of pre-existing particles favored the growth of newly-formed particles by limiting the sink linked to their collision with larger pre-existing ones, which generally hinders the observation of this kind of event at urban sites.

In Figure 9, the time series of the particle number size distribution (PNSD) and the geometric mean diameter of $\mathrm{PM}_{1}$ obtained with a scanning mobility particle sizer (SMPS) are shown together with the time series of the PMF factors and $\mathrm{PM}_{2.5}$ total mass and main inorganic ions and black carbon (BC). The NPF-like event started at $6 \mathrm{pm}$ and finished at $4 \mathrm{am}$ (local time), with an average growth rate of $5.1 \mathrm{~nm} \mathrm{~h}^{-1}$ reaching a geometric mean diameter of $70 \mathrm{~nm}$. Two 
565 phases of growth can be observed (Figure 9b): a first one with a steeper slope $\left(\mathrm{g}=6.4 \mathrm{~nm} \mathrm{~h}^{-1}\right)$, 566 between 18:00 and 23:00, corresponding to a stronger increase of the aerosol size and a second 567 one less pronounced $\left(\mathrm{g}=2.8 \mathrm{~nm} \mathrm{~h}^{-1}\right)$, between 23:00 and 04:00 the next day. During the growth 568 phase, for a given diameter in the upper range of the nucleation mode (e.g. $20 \mathrm{~nm}$ ) the particle number concentration decreased with time, whereas it increased in the Aitken mode (e.g. $60 \mathrm{~nm}$ ). At the same time, the concentrations of OA increased simultaneously up to $14 \mu \mathrm{g} \mathrm{m}^{-3}$, with oBBOA clearly dominating with a contribution higher than $50 \%$ during most of the event. The concentrations of soluble $\mathrm{K}^{+}$(not shown in the Figure) measured with the MARGA also showed the same increasing trend. This suggests that fast processing of organic matter from biomass burning emissions was strongly involved in this event. Simultaneously, increasing concentrations of $\mathrm{NO}_{3}, \mathrm{SO}_{4}$, and $\mathrm{NH}_{4}$ were observed (Figure 9d). It is likely that $\mathrm{NH}_{4} \mathrm{NO}_{3}$ played a major role in the event by condensing on the emitted fine particles from combustion processes, given the simultaneous increases - by a factor of 5.4 and 4, respectively - in the concentrations of $\mathrm{NO}_{3}$ and $\mathrm{NH}_{4}$ during the event. The observation of $\mathrm{NH}_{4} \mathrm{NO}_{3}$ as one of the main components in particle growth is quite rare. Indeed, previous studies having reported measurements of the main species responsible for particle growth have shown that the main constituents at urban and regional sites are $\mathrm{OA}$ and $\mathrm{SO}_{4}$ (Kerminen et al., 2018 and references therein). However, almost none of these studies have been conducted in North-Western Europe, where the contribution of $\mathrm{NH}_{4} \mathrm{NO}_{3}$ is typically higher and as high as 30\% (Putaud et al., 2004). Only one study carried out in Melpitz, Germany, determined $\mathrm{SO}_{4}, \mathrm{NH}_{4}$ and $\mathrm{OA}$ as the main components responsible for particle growth, although their fractional contributions were not estimated (Wu et al., 2015). In addition, most NPF events have occurred during daytime, and hence linked to a photochemical origin, in which $\mathrm{OA}$ and $\mathrm{SO}_{4}$ are the main species involved (Kulmala and Kerminen, 2008). Therefore, the nature of nighttime NPF events is likely to differ from daytime NPF events, where compounds that predominate during nighttime such as $\mathrm{NH}_{4} \mathrm{NO}_{3}$ and the oBBOA fraction of OA can play a key role. However, up to date, fewer than 10 measurement sites worldwide have reported nighttime NPF observations, and their main components are still not well-known (Kerminen et al., 2018). Among these, Man et al. (2015) also related ammonium nitrate and OA to nocturnal particle growth in Hong Kong.

\section{Conclusions}

In this study, the characteristics and sources of submicron OA were investigated during an intensive winter (5 February to 16 March 2016) in northern France. Moderate concentrations of $\mathrm{NR}_{-} \mathrm{PM}_{1}\left(11.1 \pm 9.3 \mu \mathrm{g} \mathrm{m}^{-3}\right)$ were observed, generally dominated by inorganic ions $(62 \%)$. Nitrate was the dominant inorganic ion (35.9\%), followed by $\mathrm{NH}_{4}(15.9 \%)$ and $\mathrm{SO}_{4}(8.8 \%)$. In addition, the NR (neutralization ratio) of the aerosol was close to 1 during most of the campaign, implying that there was always enough $\mathrm{NH}_{4}$ to neutralize $\mathrm{NO}_{3}$ and $\mathrm{SO}_{4}$.

OA was found to be moderately oxidized $(\mathrm{O}: \mathrm{C}=0.32)$ and evolving along a slope of -1 in 605 the Van Krevelen plot ( $\mathrm{H}: \mathrm{C}$ vs $\mathrm{O}: \mathrm{C}$ ) indicating that the simultaneous addition of carbonyl and alcohol groups could be predominant in the oxidation of OA. Application of the PMF analysis to 
the OA mass spectra revealed the presence of several types of OA at the sampling location. Identified OA were denoted as hydrocarbon-like (HOA), oxidized biomass burning (oBBOA), and two oxygenated factors classified into less oxidized (LO-OOA) and more oxidized (MOOOA). The concentrations of the oBBOA factor were positively correlated with relative humidity, suggesting aqueous processing of primary biomass burning emissions took place. This was supported by high values of OM:OC and O:C during nighttime and by the NWR analysis which showed higher oBBOA concentrations for calm winds indicating local origins. On average, OA was dominated by MO-OOA (35\%) and oBBOA (28\%). In addition, oBBOA, water-soluble $\mathrm{K}^{+}$and $\mathrm{NH}_{4} \mathrm{NO}_{3}$ were shown to be involved in a nighttime NPF-like event during period I, suggesting a condensation of SIA on freshly emitted fine particles. However, during the last part of the campaign (5 to 16 March 2016) the contribution of the LO-OOA factor increased up to $34 \%$. During the first period of the campaign (5 February to 4 March 2016) the origin of the air masses alternated from oceanic and continental, which led to low to moderate concentrations

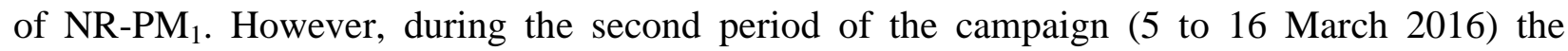
sampling site was heavily impacted by air masses from Eastern Europe rich in aged aerosols, evidenced by the high contributions from secondary inorganic and organic aerosols. In combination with an anticyclonic situation and low ventilation coefficient values, this favored the presence of high NR-PM 1 concentrations in the north of France. Lastly, the OA confined into a narrower space in the $\mathrm{VK}$ diagram during the last period of the campaign, suggesting a homogenization of the different aerosol sources due to ageing of OA during transportation.

These results indicate that during winter, aqueous processing of primary biomass burning emissions in North-Western Europe could be more important than what was previously thought, and even involved in NPF-like events during nighttime under specific meteorological conditions (clean and stagnant air masses, low temperatures, high relative humidity). In addition, air masses arriving from Eastern Europe have a considerable impact in the region of northern France, with higher concentrations of secondary inorganic and organic aerosols. Hence, the improvement of the mitigation policies in neighboring countries of France, mainly Belgium, Germany and Poland, should exert a significant impact on the air quality.

\section{Acknowledgments}

IMT Lille Douai acknowledges financial support from the CaPPA project, which is funded by the French National Research Agency (ANR) through the PIA (Programme d'Investissement d'Avenir) under contract ANR-11-LABX-0005-01, the CLIMIBIO project, both financed by the Regional Council "Hauts-de-France" and the European Regional Development Fund (ERDF). This field campaign was carried out within the framework of the ISARD project funded by the AACT-AIR (ADEME) program (grant 1562C0011). R. Roig Rodelas thanks ARMINES for his PhD fellowship. The authors thank Atmo Hauts-de-France and Météo-France for providing air monitoring and meteorological data, respectively.

\section{References}


Alfarra, M. R., Coe, H., Allan, J. D., Bower, K. N., Boudries, H., Canagaratna, M. R., Jimenez, J. L., Jayne, J. T., Garforth, A. A., Li, S. M. and Worsnop, D. R.: Characterization of urban and rural organic particulate in the Lower Fraser Valley using two Aerodyne Aerosol Mass Spectrometers, Atmospheric Environment, 38, 5745-5758, doi:10.1016/j.atmosenv.2004.01.054, 2004.

Alfarra, M. R., Prévôt, A. S. H., Szidat, S., Sandradewi, J., Weimer, S., Lanz, V. A., Schreiber, D., Mohr, M. and Baltensperger, U.: Identification of the mass spectral signature of organic aerosols from wood burning emissions, Environmental Science \& Technology, 41(16), 5770-5777, doi:10.1021/es062289b, 2007.

655 Allan, J. D., Delia, A. E., Coe, H., Bower, K. N., Alfarra, M. R., Jimenez, J. L., Middlebrook, A. M., 656 Drewnick, F., Onasch, T. B., Canagaratna, M. R., Jayne, J. T. and Worsnop, D. R.: A generalised method 657 for the extraction of chemically resolved mass spectra from Aerodyne aerosol mass spectrometer 658 data, Journal of Aerosol Science, 35(7), 909-922, doi:10.1016/j.jaerosci.2004.02.007, 2004.

659 Allen, G. A., Babich, P. and Poirot, R. L.: Evaluation of a New Approach for Real Time Assessment of 660 Wood Smoke PM, in Proceedings of the Regional and Global Perspectives on Haze: Causes, 661 Consequences, and Controversies, NC: Air and Waste Management Association Visibility Specialty 662 Conference, paper 16., 2004.

663 Atmo Nord-Pas-de-Calais: Bilan Annuel 2013 - Rapport Integral., 2014.

664 Bozzetti, C., El Haddad, I., Salameh, D., Daellenbach, K. R., Fermo, P., Gonzalez, R., Minguillón, M. C., 665 Iinuma, Y., Poulain, L., Elser, M., Müller, E., Slowik, J. G., Jaffrezo, J.-L., Baltensperger, U., Marchand, N. and Prévôt, A. S. H.: Organic aerosol source apportionment by offline-AMS over a full year in Marseille, Atmos. Chem. Phys., 17(13), 8247-8268, doi:10.5194/acp-17-8247-2017, 2017.

668

669

ten Brink, H., Otjes, R., Jongejan, P. and Slanina, S.: An instrument for semi-continuous monitoring of the size-distribution of nitrate, ammonium, sulphate and chloride in aerosol, Atmospheric Environment, 41(13), 2768-2779, doi:10.1016/j.atmosenv.2006.11.041, 2007. organic aerosol next to a major roadway, Journal of the Air \& Waste Management Association, 63(12), 1422-1433, doi:10.1080/10962247.2013.826602, 2013. 573, doi:10.1080/02786820490465504, 2004.

678 Canagaratna, M. R., Jayne, J. T., Jimenez, J. L., Allan, J. D., Alfarra, M. R., Zhang, Q., Onasch, T. B., 679 Drewnick, F., Coe, H., Middlebrook, A., Delia, A., Williams, L. R., Trimborn, A. M., Northway, M. J., 680 DeCarlo, P. F., Kolb, C. E., Davidovits, P. and Worsnop, D. R.: Chemical and microphysical 681 characterization of ambient aerosols with the aerodyne aerosol mass spectrometer, Mass 682 Spectrometry Reviews, 26(2), 185-222, doi:10.1002/mas.20115, 2007.

683 Chakraborty, A., Bhattu, D., Gupta, T., Tripathi, S. N. and Canagaratna, M. R.: Real-time measurements 684 of ambient aerosols in a polluted Indian city: Sources, characteristics, and processing of organic 685 aerosols during foggy and nonfoggy periods, Journal of Geophysical Research, 120(17), 686 doi:10.1002/2015JD023419, 2015. 

background site and an industrialized coastal site in Northern France - Part 3: Sources, composition, and evolution of organic aerosols, n.d.

690 Cheung, H. C., Morawska, L. and Ristovski, Z. D.: Observation of new particle formation in subtropical urban environment, Atmos. Chem. Phys., 11(8), 3823-3833, doi:10.5194/acp-11-3823-2011, 2011.

692 Crenn, V., Fronval, I., Petitprez, D. and Riffault, V.: Fine particles sampled at an urban background site and an industrialized coastal site in Northern France - Part 1: Seasonal variations and chemical characterization, Science of The Total Environment, 578(February), 203-218, doi:10.1016/j.scitotenv.2015.11.165, 2017a.

696 Crenn, V., Chakraborty, A., Fronval, I., Petitprez, D. and Riffault, V.: Fine particles sampled at an urban background site and an industrialized coastal site in Northern France-Part 2: Comparison of offline and online analyses for carbonaceous aerosols, Aerosol Science and Technology, doi:10.1080/02786826.2017.1403008, 2017b.

700 Crippa, M., Decarlo, P. F., Slowik, J. G., Mohr, C., Heringa, M. F., Chirico, R., Poulain, L., Freutel, F., 701 Sciare, J., Cozic, J., Di Marco, C. F., Elsasser, M., Nicolas, J. B., Marchand, N., Abidi, E., Wiedensohler, A., 702 Drewnick, F., Schneider, J., Borrmann, S., Nemitz, E., Zimmermann, R., Jaffrezo, J. L., Prévôt, A. S. H. and Baltensperger, U.: Wintertime aerosol chemical composition and source apportionment of the organic fraction in the metropolitan area of Paris, Atmospheric Chemistry and Physics, 13, 961-981, doi:10.5194/acp-13-961-2013, 2013.

706

Crippa, M., Canonaco, F., Lanz, V. A., Aijala, M., Allan, J. D., Carbone, S., Capes, G., Ceburnis, D., Dall'Osto, M., Day, D. A., DeCarlo, P. F., Ehn, M., Eriksson, A., Freney, E., Ruiz, L. H., Hillamo, R., Jimenez, J. L., Junninen, H., Kiendler-Scharr, A., Kortelainen, A. M., Kulmala, M., Laaksonen, A., Mensah, A., Mohr, C., Nemitz, E., O’Dowd, C., Ovadnevaite, J., Pandis, S. N., Petaja, T., Poulain, L., Saarikoski, S., Sellegri, K., Swietlicki, E., Tiitta, P., Worsnop, D. R., Baltensperger, U. and Prevot, A. S. H.: Organic aerosol components derived from 25 AMS data sets across Europe using a consistent ME-2 based source apportionment approach, Atmospheric Chemistry and Physics, 14(12), 61596176, doi:10.5194/acp-14-6159-2014, 2014.

714

Dall'Osto, M., Harrison, R. M., Coe, H. and Williams, P.: Real-time secondary aerosol formation during a fog event in London, Atmospheric Chemistry and Physics, 9(7), 2459-2469, doi:10.5194/acp-92459-2009, 2009.

717 DeCarlo, P. F., Kimmel, J. R., Trimborn, A., Northway, M. J., Jayne, J. T., Aiken, A. C., Gonin, M., Fuhrer, 718 K., Horvath, T., Docherty, K. S., Worsnop, D. R. and Jimenez, J. L.: Field-deployable, high-resolution, 719 time-of-flight aerosol mass spectrometer, Analytical Chemistry, 78, 8281-8289, 720 doi:10.1021/ac061249n, 2006.

Docherty, K. S., Aiken, A. C., Huffman, J. A., Ulbrich, I. M., DeCarlo, P. F., Sueper, D., Worsnop, D. R., Snyder, D. C., Peltier, R. E., Weber, R. J., Grover, B. D., Eatough, D. J., Williams, B. J., Goldstein, A. H., Ziemann, P. J. and Jimenez, J. L.: The 2005 Study of Organic Aerosols at Riverside (SOAR-1): instrumental intercomparisons and fine particle composition, Atmospheric Chemistry and Physics, 11(23), 12387-12420, doi:10.5194/acp-11-12387-2011, 2011.

726 Drewnick, F., Hings, S. S., DeCarlo, P., Jayne, J. T., Gonin, M., Fuhrer, K., Weimer, S., Jimenez, J. L., 727 Demerjian, K. L., Borrmann, S. and Worsnop, D. R.: A New Time-of-Flight Aerosol Mass Spectrometer 
(TOF-AMS)-Instrument Description and First Field Deployment, Aerosol Science and Technology, 39(7), 637-658, doi:10.1080/02786820500182040, 2005.

730 Eagleman, J. R.: Air pollution meteorology, Kansas: Tr., 1991.

731 Fiedler, V., Dal Maso, M., Boy, M., Aufmhoff, H., Hoffmann, J., Schuck, T., Birmili, W., Hanke, M., Uecker, J., Arnold, F. and Kulmala, M.: The contribution of sulphuric acid to atmospheric particle formation and growth: a comparison between boundary layers in Northern and Central Europe, Atmos. Chem. Phys., 5(7), 1773-1785, doi:10.5194/acp-5-1773-2005, 2005.

Florou, K., Papanastasiou, D. K., Pikridas, M., Kaltsonoudis, C., Louvaris, E., Gkatzelis, G. I., Patoulias, D., Mihalopoulos, N. and Pandis, S. N.: The contribution of wood burning and other pollution sources to wintertime organic aerosol levels in two Greek cities, Atmospheric Chemistry and Physics, 17(4), 3145-3163, doi:10.5194/acp-17-3145-2017, 2017.

Ge, X., Zhang, Q., Sun, Y., Ruehl, C. R. and Setyan, A.: Effect of aqueous-phase processing on aerosol chemistry and size distributions in Fresno, California, during wintertime, Environmental Chemistry, 9(3), 221-235, doi:10.1071/en11168, 2012.

Gilardoni, S., Massoli, P., Paglione, M., Giulianelli, L., Carbone, C., Rinaldi, M., Decesari, S., Sandrini, S., Costabile, F., Gobbi, G. P., Pietrogrande, M. C., Visentin, M., Scotto, F., Fuzzi, S. and Facchini, M. C.: Direct observation of aqueous secondary organic aerosol from biomass-burning emissions., Proceedings of the National Academy of Sciences of the United States of America, 113(36), 1001310018, doi:10.1073/pnas.1602212113, 2016. 27-39, doi:10.1016/j.scitotenv.2007.01.067, 2007.

Hallquist, M., Wenger, J. C., Baltensperger, U., Rudich, Y., Simpson, D., Claeys, M., Dommen, J., Donahue, N. M., George, C., Goldstein, A. H., Hamilton, J. F., Herrmann, H., Hoffmann, T., Iinuma, Y., Jang, M., Jenkin, M. E., Jimenez, J. L., Kiendler-Scharr, A., Maenhaut, W., McFiggans, G., Mentel, T. F., Monod, A., Prévôt, A. S. H., Seinfeld, J. H., Surratt, J. D., Szmigielski, R. and Wildt, J.: The formation, properties and impact of secondary organic aerosol: current and emerging issues, Atmospheric Chemistry and Physics, 9(14), 5155-5236, 2009.

760 Hayes, P. L., Ortega, A. M., Cubison, M. J., Froyd, K. D., Zhao, Y., Cliff, S. S., Hu, W. W., Toohey, D. W.,

Hamed, A., Joutsensaari, J., Mikkonen, S., Sogacheva, L., Dal Maso, M., Kulmala, M., Cavalli, F., Fuzzi, S., Facchini, M. C., Decesari, S., Mircea, M., Lehtinen, K. E. J. and Laaksonen, A.: Nucleation and growth of new particles in Po Valley, Italy, Atmos. Chem. Phys., 7(2), 355-376, doi:10.5194/acp-7-355-2007, 2007.

762

763

764

765

766

767 Flynn, J. H., Lefer, B. L., Grossberg, N., Alvarez, S., Rappenglück, B., Taylor, J. W., Allan, J. D., Holloway, J. S., Gilman, J. B., Kuster, W. C., De Gouw, J. A., Massoli, P., Zhang, X., Liu, J., Weber, R. J., Corrigan, A. L., Russell, L. M., Isaacman, G., Worton, D. R., Kreisberg, N. M., Goldstein, A. H., Thalman, R., Waxman, E. M., Volkamer, R., Lin, Y. H., Surratt, J. D., Kleindienst, T. E., Offenberg, J. H., Dusanter, S., Griffith, S., Stevens, P. S., Brioude, J., Angevine, W. M. and Jimenez, J. L.: Organic aerosol composition and sources in Pasadena, California, during the 2010 CalNex campaign, Journal of Geophysical Research D: Atmospheres, 118, 9233-9257, doi:10.1002/jgrd.50530, 2013. 
Heald, C. L., Kroll, J. H., Jimenez, J. L., Docherty, K. S., Decarlo, P. F., Aiken, A. C., Chen, Q., Martin, S. T., Farmer, D. K. and Artaxo, P.: A simplified description of the evolution of organic aerosol composition in the atmosphere, Geophysical Research Letters, 37(8), doi:10.1029/2010GL042737., 2010.

Heintzenberg, J., Wehner, B. and Birmili, W.: 'How to find bananas in the atmospheric aerosol': new approach for analyzing atmospheric nucleation and growth events, Tellus B, 59(2), 273-282, doi:10.1111/j.1600-0889.2007.00249.x, 2007.

Henry, R., Norris, G. a, Vedantham, R. and Turner, J. R.: Source region identification using kernel smoothing., Environmental science \& technology, 43(11), 4090-4097, doi:10.1021/es8011723, 2009.

Iida, K., Stolzenburg, M. R., McMurry, P. H. and Smith, J. N.: Estimating nanoparticle growth rates from size-dependent charged fractions: Analysis of new particle formation events in Mexico City, J. Geophys. Res., 113(D5), D05207, doi:10.1029/2007JD009260, 2008.

780 IPCC: Climate Change 2013: The Physical Science Basis. Contribution of Working Group I to the Fifth Assessment Report of the Intergovernmental Panel on Climate Change, Cambridge, United Kingdom and New York, NY, USA. [online] Available from: http://www.ipcc.ch/report/ar5/wg1/, 2013.

Jimenez, J. L.: Ambient aerosol sampling using the Aerodyne Aerosol Mass Spectrometer, Journal of Geophysical Research, 108, doi:10.1029/2001JD001213, 2003.

Jimenez, J. L., Canagaratna, M. R., Donahue, N. M., Prévôt, A. S. H., Zhang, Q., Kroll, J. H., DeCarlo, P. F., Allan, J. D., Coe, H., Ng, N. L., Aiken, A. C., Docherty, K. S., Ulbrich, I. M., Grieshop, A. P., Robinson, A. L., Duplissy, J., Smith, J. D., Wilson, K. R., Lanz, V. A., Hueglin, C., Sun, Y. L., Tian, J., Laaksonen, A., Raatikainen, T., Rautiainen, J., Vaattovaara, P., Ehn, M., Kulmala, M., Tomlinson, J. M., Collins, D. R., Cubison, M. J., Dunlea, E. J., Huffman, J. A., Onasch, T. B., Alfarra, M. R., Williams, P. I., Bower, K., Kondo, Y., Schneider, J., Drewnick, F., Borrmann, S., Weimer, S., Demerjian, K., Salcedo, D., Cottrell, L., Griffin, R., Takami, A., Miyoshi, T., Hatakeyama, S., Shimono, A., Sun, J. Y., Zhang, Y. M., Dzepina, K., Kimmel, J. R., Sueper, D., Jayne, J. T., Herndon, S. C., Trimborn, A. M., Williams, L. R., Wood, E. C., Middlebrook, A. M., Kolb, C. E., Baltensperger, U. and Worsnop, D. R.: Evolution of Organic Aerosols in the Atmosphere, Science (New York, N.Y.), 326(5959), 1525-1529, doi:10.1126/science.1180353, 2009.

Kanakidou, M., Seinfeld, J. H., Pandis, S. N., Barnes, I., Dentener, F. J., Facchini, M. C., Van Dingenen, R., Ervens, B., Nenes, A., Nielsen, C. J., Swietlicki, E., Putaud, J. P., Balkanski, Y., Fuzzi, S., Horth, J., Moortgat, G. K., Winterhalter, R., Myhre, C. E. L., Tsigaridis, K., Vignati, E., Stephanou, E. G. and Wilson, J.: Organic aerosol and global climate modelling: a review, Atmospheric Chemistry and Physics, 5, 1053-1123, doi:10.5194/acp-5-1053-2005, 2005.

801 Kelly, F. J. and Fussell, J. C.: Size, source and chemical composition as determinants of toxicity 802 attributable to ambient particulate matter, Atmospheric Environment, 60, 504-526, 803 doi:10.1016/j.atmosenv.2012.06.039, 2012.

804 Kerminen, V.-M., Chen, X., Vakkari, V., Petäjä, T., Kulmala, M. and Bianchi, F.: Atmospheric new doi:10.1088/1748-9326/aadf3c, 2018.

807 Kulmala, M. and Kerminen, V.-M.: On the formation and growth of atmospheric nanoparticles, 808 Atmospheric Research, 90(2), 132-150, doi:10.1016/j.atmosres.2008.01.005, 2008. 

C., Schneider, J., Favez, O., D'Anna, B., George, C. and Baltensperger, U.: Characterization of aerosol chemical composition with aerosol mass spectrometry in Central Europe: an overview, Atmospheric Chemistry and Physics, 10(21), 10453-10471, doi:10.5194/acp-10-10453-2010, 2010.

813 Li, Y. J., Lee, B. Y. L., Yu, J. Z., Ng, N. L. and Chan, C. K.: Evaluating the degree of oxygenation of organic aerosol during foggy and hazy days in Hong Kong using high-resolution time-of-flight aerosol mass spectrometry (HR-ToF-AMS), Atmospheric Chemistry and Physics, 13(17), 8739-8753, doi:10.5194/acp-13-8739-2013, 2013.

817 Li, Y. J., Huang, D. D., Cheung, H. Y., Lee, A. K. Y. and Chan, C. K.: Aqueous-phase photochemical 818 oxidation and direct photolysis of vanillin - a model compound of methoxy phenols from biomass 819 burning, Atmospheric Chemistry and Physics, 14(6), 2871-2885, doi:10.5194/acp-14-2871-2014, 8202014.

821 Man, H., Zhu, Y., Ji, F., Yao, X., Lau, N. T., Li, Y., Lee, B. P. and Chan, C. K.: Comparison of Daytime and 822 Nighttime New Particle Growth at the HKUST Supersite in Hong Kong, Environ. Sci. Technol., 49(12), 823 7170-7178, doi:10.1021/acs.est.5b02143, 2015.

Middlebrook, A. M., Bahreini, R., Jimenez, J. L. and Canagaratna, M. R.: Evaluation of CompositionDependent Collection Efficiencies for the Aerodyne Aerosol Mass Spectrometer using Field Data, Aerosol Science and Technology, 46(3), 258-271, doi:10.1080/02786826.2011.620041, 2012. Hannigan, M. and Jimenez, J. L.: Characterization of Primary Organic Aerosol Emissions from Meat Cooking, Trash Burning, and Motor Vehicles with High-Resolution Aerosol Mass Spectrometry and Comparison with Ambient and Chamber Observations, Environmental Science \& Technology, 43(7), 2443-2449, doi:10.1021/es8011518, 2009.

832

833

834

835

836

Mohr, C., DeCarlo, P. F., Heringa, M. F., Chirico, R., Slowik, J. G., Richter, R., Reche, C., Alastuey, A., Querol, X., Seco, R., Peñuelas, J., Jiḿenez, J. L., Crippa, M., Zimmermann, R., Baltensperger, U. and Prév̂ot, A. S. H.: Identification and quantification of organic aerosol from cooking and other sources in Barcelona using aerosol mass spectrometer data, Atmospheric Chemistry and Physics, 12(4), 1649-1665, doi:10.5194/acp-12-1649-2012, 2012.

838

Paatero, P. and Tapper, U.: Positive Matrix Factorization - A Nonnegative Factor Model with Optimal Utilization of Error Estimates of Data Values, Environmetrics, 5, 111-126, doi:10.1002/env.3170050203, 1994.

840 Pan, Y.-L.: Detection and characterization of biological and other organic-carbon aerosol particles in 841 atmosphere using fluorescence, Journal of Quantitative Spectroscopy and Radiative Transfer, 150, $842 \quad 12-35$, doi:10.1016/j.jqsrt.2014.06.007, 2015.

843 Petit, J.-E., Favez, O., Albinet, A. and Canonaco, F.: A user-friendly tool for comprehensive evaluation 844 of the geographical origins of atmospheric pollution: Wind and trajectory analyses, Environmental 845 Modelling \& Software, 88(February), 183-187, doi:10.1016/j.envsoft.2016.11.022, 2017.

846 Poulain, L., Iinuma, Y., Mueller, K., Birmili, W., Weinhold, K., Brueggemann, E., Gnauk, T., Hausmann, 847 A., Loeschau, G., Wiedensohler, A. and Herrmann, H.: Diurnal variations of ambient particulate wood 848 burning emissions and their contribution to the concentration of Polycyclic Aromatic Hydrocarbons 
851 Putaud, J.-P., Raes, F., Van Dingenen, R., Brüggemann, E., Facchini, M.-C., Decesari, S., Fuzzi, S., Gehrig, R., Hüglin, C., Laj, P., Lorbeer, G., Maenhaut, W., Mihalopoulos, N., Müller, K., Querol, X., Rodriguez, S., Schneider, J., Spindler, G., Brink, H. ten, Tørseth, K. and Wiedensohler, A.: A European aerosol phenomenology-2: chemical characteristics of particulate matter at kerbside, urban, rural and background sites in Europe, Atmos. Environ., 38(16), 2579-2595, doi:10.1016/j.atmosenv.2004.01.041, 2004.

857 Roig Rodelas, R., Perdrix, E., Herbin, B. and Riffault, V.: Characterization and variability of inorganic 858 aerosols and their gaseous precursors at a suburban site in northern France over one year (2015859 2016), Atmos. Environ. 200, 142-157, doi:10.1016/j.atmosenv.2018.11.041, 2019.

860 Saarikoski, S., Carbone, S., Decesari, S., Giulianelli, L., Angelini, F., Canagaratna, M., Ng, N. L., 861 Trimborn, A., Facchini, M. C., Fuzzi, S., Hillamo, R. and Worsnop, D.: Chemical characterization of 862 springtime submicrometer aerosol in Po Valley, Italy, Atmospheric Chemistry and Physics, 12(18), 863 8401-8421, doi:10.5194/acp-12-8401-2012, 2012.

864 Salimi, F., Rahman, M. M., Clifford, S., Ristovski, Z. and Morawska, L.: Nocturnal new particle formation events in urban environments, Atmos. Chem. Phys., 17(1), 521-530, doi:10.5194/acp-17521-2017, 2017.

867 Seinfeld, J. H. and Pandis, S. N.: Wiley: Atmospheric Chemistry and Physics: From Air Pollution to 868 Climate Change, 2nd Edition., 2006. F.: Growth rates of freshly nucleated atmospheric particles in Atlanta, J. Geophys. Res., 110(D22), D22S05, doi:10.1029/2005JD005935, 2005. Rome, Italy: sources, dynamics and spatial variations during two seasons, Atmospheric Chemistry and Physics, 16(23), 15277-15299, doi:10.5194/acp-16-15277-2016, 2016. Decesari, S., Facchini, M. C., Poulain, L., Herrmann, H., Wiedensohler, A., Nemitz, E., Twigg, M. M. and Collett Jr., J. L.: Evidence for ambient dark aqueous SOA formation in the Po Valley, Italy, Atmospheric Chemistry and Physics, 16(13), 8095-8108, doi:10.5194/acp-16-8095-2016, 2016.

879 Sun, Y. L., Zhang, Q., Anastasio, C. and Sun, J.: Insights into secondary organic aerosol formed via 880 aqueous-phase reactions of phenolic compounds based on high resolution mass spectrometry, 881 Atmospheric Chemistry and Physics, 10(10), 4809-4822, doi:10.5194/acp-10-4809-2010, 2010.

882 Timonen, H., Carbone, S., Aurela, M., Saarnio, K., Saarikoski, S., Ng, N. L., Canagaratna, M. R., Kulmala, 883 M., Kerminen, V.-M., Worsnop, D. R. and Hillamo, R.: Characteristics, sources and water-solubility of 884 ambient submicron organic aerosol in springtime in Helsinki, Finland, Journal of Aerosol Science, 885 56, 61-77, doi:10.1016/j.jaerosci.2012.06.005, 2013.

886 Ulbrich, I. M., Canagaratna, M. R., Zhang, Q., Worsnop, D. R. and Jimenez, J. L.: Interpretation of 887 888 organic components from Positive Matrix Factorization of aerosol mass spectrometric data, Atmospheric Chemistry and Physics, 9(9), 2891-2918, 2009. 
889

890

891

892

893

894

895

896

897

898

899

900

901

902

903

904

905

906

907

908

909

910

911

912

913

914

915

916

917

918
Wallace, H. W., Sanchez, N. P., Flynn, J. H., Erickson, M. H., Lefer, B. L. and Griffin, R. J.: Source apportionment of particulate matter and trace gases near a major refinery near the Houston Ship Channel, Atmospheric Environment, 173, 16-29, doi:10.1016/j.atmosenv.2017.10.049, 2018.

Wang, Y., Hopke, P. K., Rattigan, O. V, Chalupa, D. C. and Utell, M. J.: Multiple-year black carbon measurements and source apportionment using Delta-C in Rochester, New York, Journal of the Air \& Waste Management Association, 62(8), 880-887, doi:10.1080/10962247.2012.671792, 2012.

Watson, J. G.: Visibility: Science and regulation, Journal of the Air \& Waste Management Association, 52(6), 628-713, 2002.

WHO: Burden of disease from the joint effects of household and ambient Air pollution for 2016., 2018.

Williams, B. J., Goldstein, A. H., Millet, D. B., Holzinger, R., Kreisberg, N. M., Hering, S. V, White, A. B., Worsnop, D. R., Allan, J. D. and Jimenez, J. L.: Chemical speciation of organic aerosol during the International Consortium for Atmospheric Research on Transport and Transformation 2004: Results from in situ measurements, Journal of Geophysical Research-Atmospheres, 112(D10), doi:10.1029/2006jd007601, 2007.

Wu, Z., Hu, M., Liu, S., Wehner, B., Bauer, S., Ma ßling, A., Wiedensohler, A., Petäjä, T., Dal Maso, M. and Kulmala, M.: New particle formation in Beijing, China: Statistical analysis of a 1-year data set, J. Geophys. Res., 112(D9), D09209, doi:10.1029/2006JD007406, 2007.

Wu, Z. J., Poulain, L., Birmili, W., Größ, J., Niedermeier, N., Wang, Z. B., Herrmann, H. and Wiedensohler, A.: Some insights into the condensing vapors driving new particle growth to CCN sizes on the basis of hygroscopicity measurements, Atmospheric Chemistry and Physics, 15(22), 13071-13083, doi:https://doi.org/10.5194/acp-15-13071-2015, 2015.

Xu, J., Shi, J., Zhang, Q., Ge, X., Canonaco, F., Prévôt, A. S. H., Vonwiller, M., Szidat, S., Ge, J., Ma, J., An, Y., Kang, S. and Qin, D.: Wintertime organic and inorganic aerosols in Lanzhou, China: sources, processes, and comparison with the results during summer, Atmos. Chem. Phys., 16(23), 1493714957, doi:https://doi.org/10.5194/acp-16-14937-2016, 2016.

Zhou, W., Wang, Q., Zhao, X., Xu, W., Chen, C., Du, W., Zhao, J., Canonaco, F., Prévôt, A. S. H., Fu, P., Wang, Z., Worsnop, D. R. and Sun, Y.: Characterization and source apportionment of organic aerosol at $260 \mathrm{~m}$ on a meteorological tower in Beijing, China, Atmos. Chem. Phys., 18(6), 3951-3968, doi:https://doi.org/10.5194/acp-18-3951-2018, 2018. 


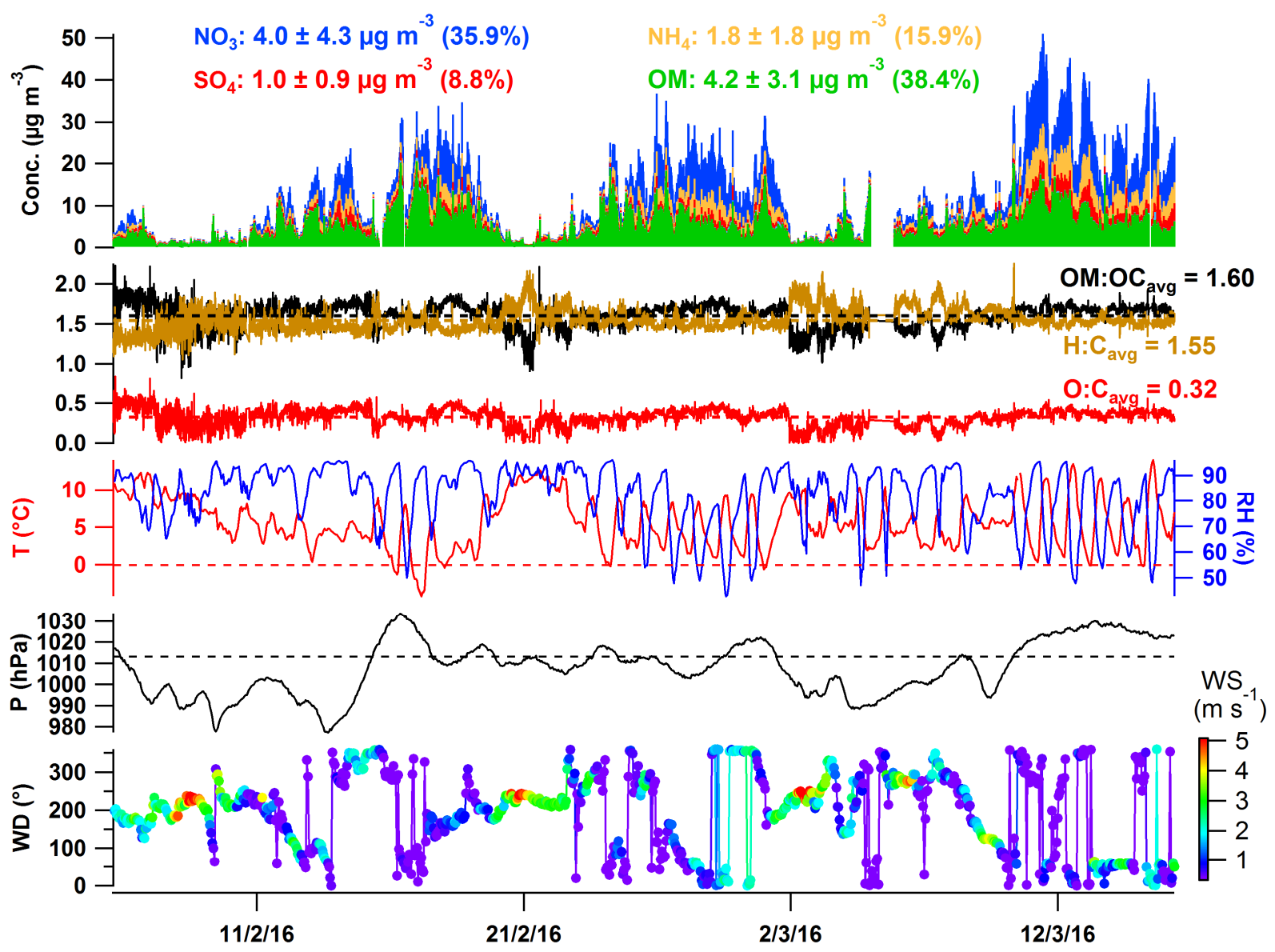

Figure 1. Time series of $\mathrm{NR}-\mathrm{PM}_{1}$, elemental ratios (OM:OC, $\mathrm{H}: \mathrm{C}$ and $\left.\mathrm{O}: \mathrm{C}\right)$ and of the main meteorological parameters (T: temperature, RH: relative humidity, P: atmospheric pressure, WD: wind direction and WS: wind speed) 


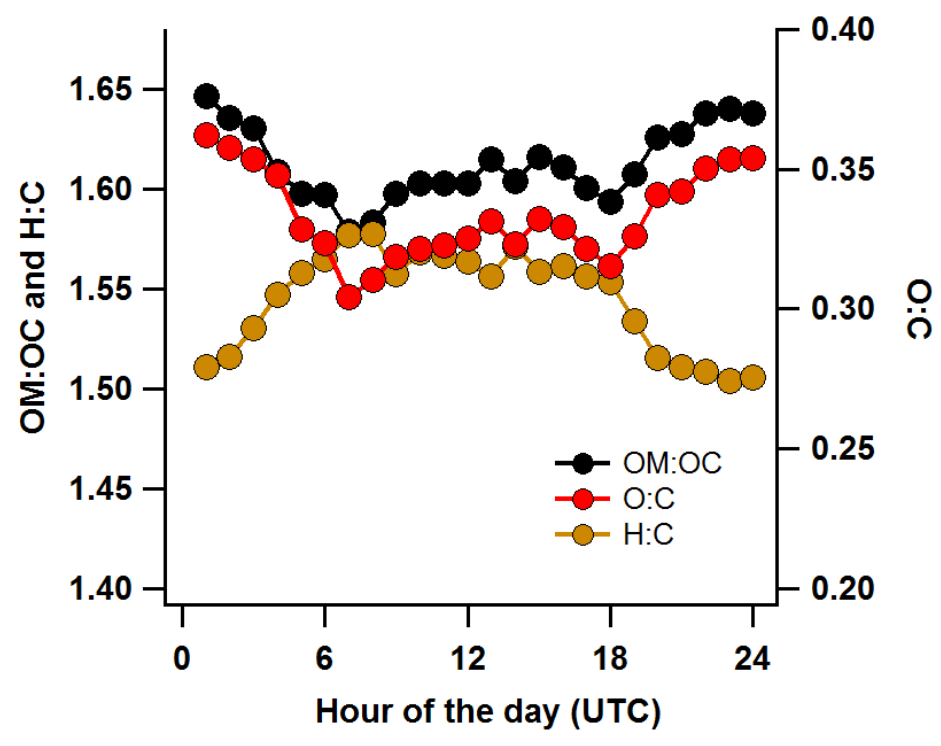

927

928

929

Figure 2. Median daily profiles for OM:OC, O:C and $\mathrm{H}: \mathrm{C}$ 


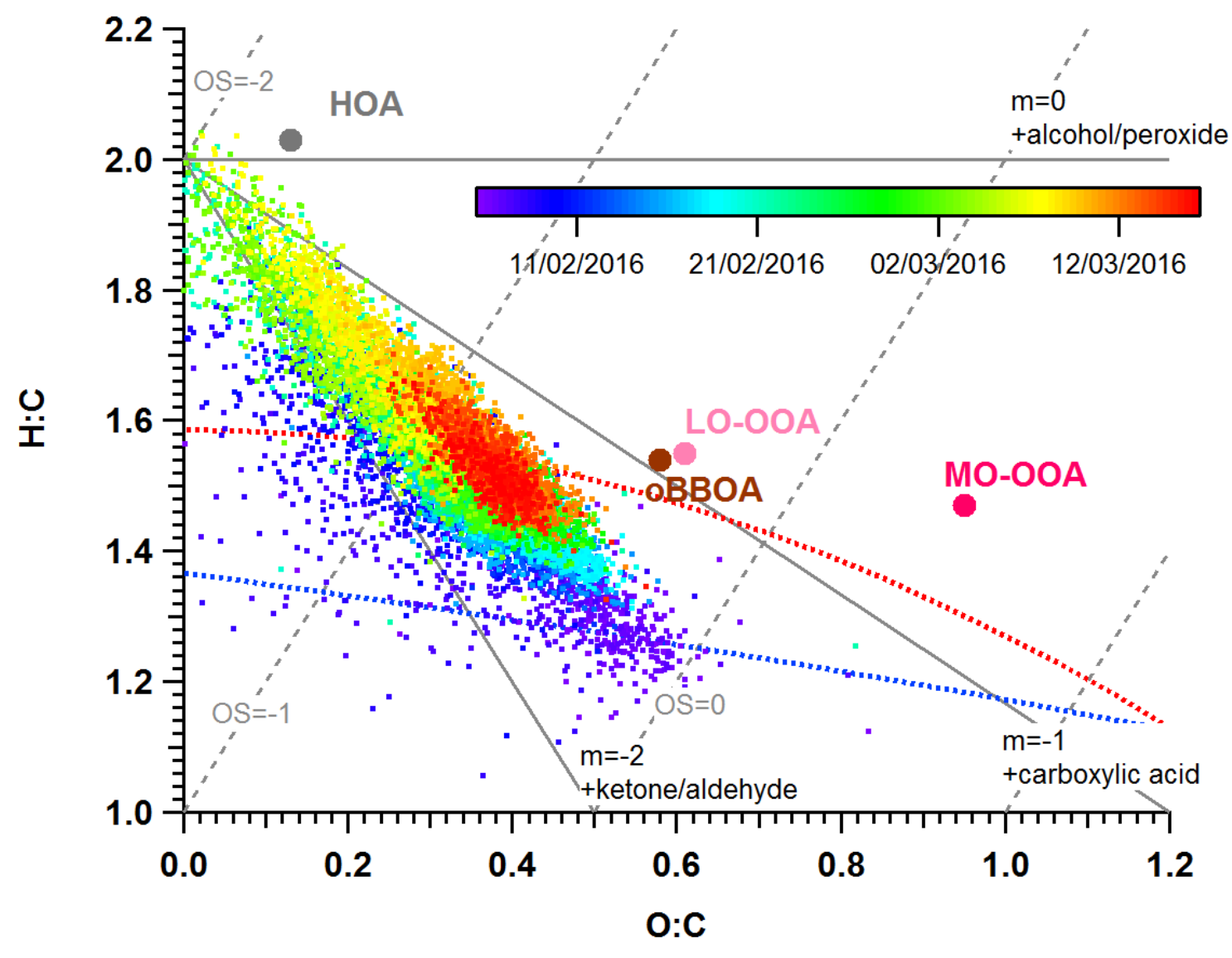

Figure 3. Van Krevelen diagram for all the data colored by time, with identified PMF factors 933 (HOA: Hydrogen-like OA, oBBOA: oxidized biomass burning OA, MO-OOA: more oxidized 934 935 oxygenated OA, LO-OOA: less oxidized - oxygenated OA). 
a)

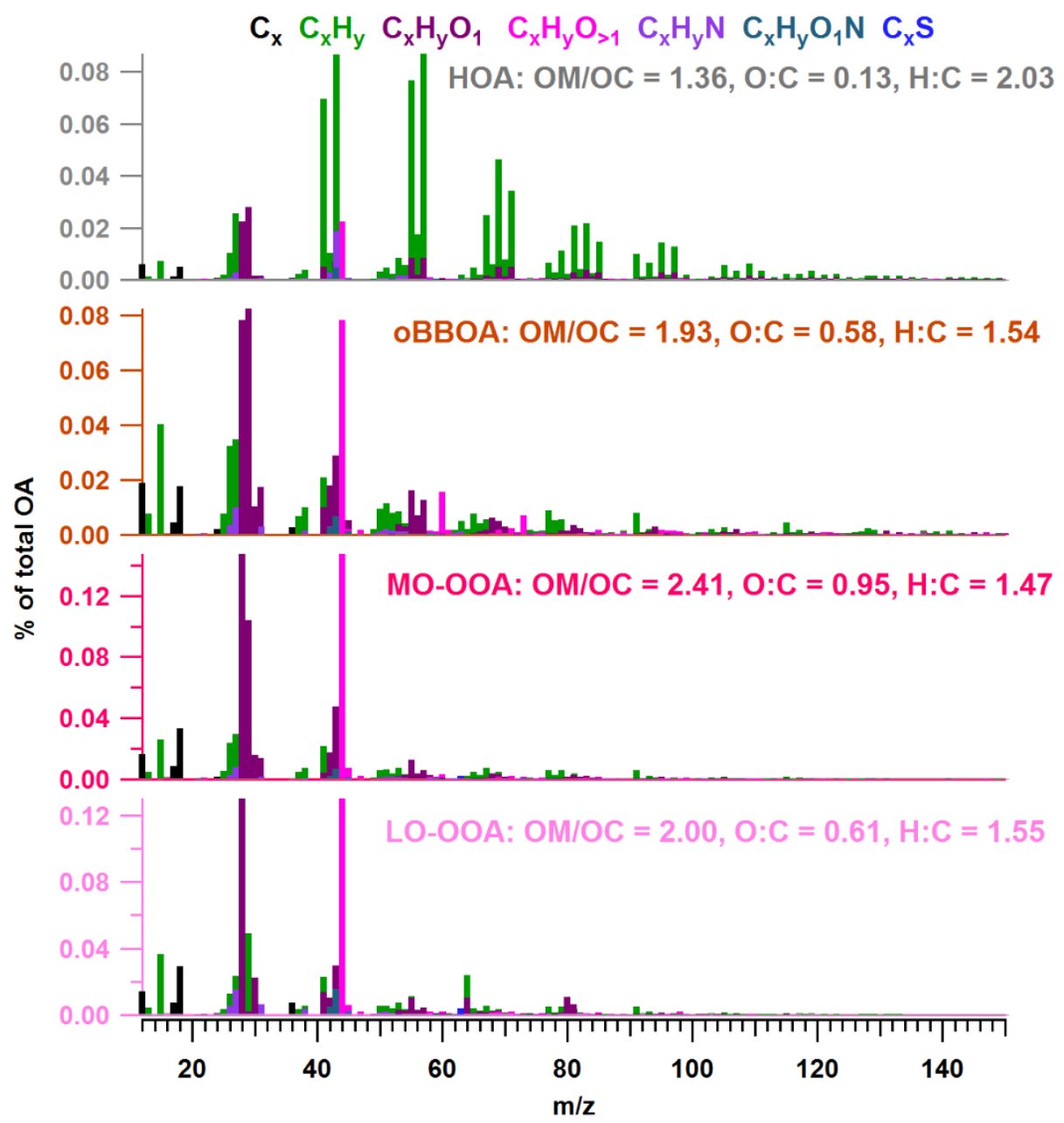

b)

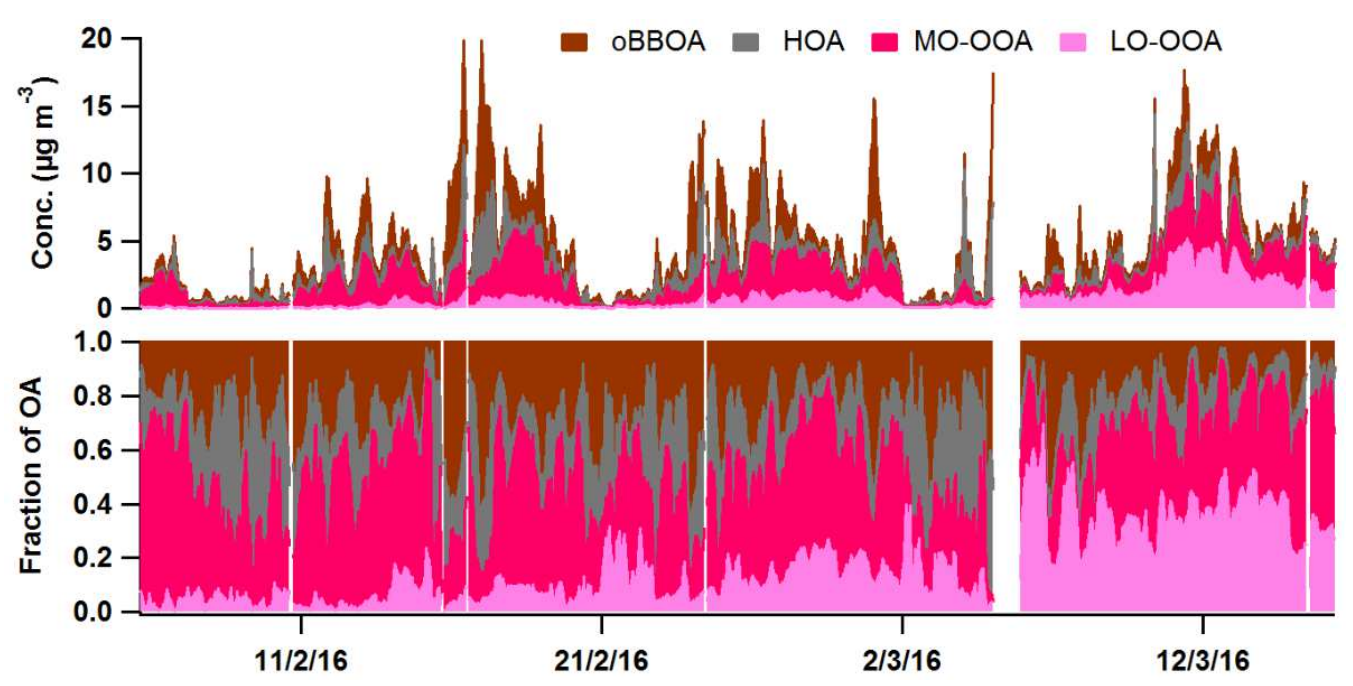

936 Figure 4. (a) Factor profiles with fragments colored by chemical families, and (b) time series of the concentrations and mass fractions of the PMF factors (HOA: Hydrogen-like OA, oBBOA: 938 oxidized biomass burning OA, MO-OOA: more oxidized - oxygenated OA, LO-OOA: less 939 oxidized - oxygenated OA). 
a)

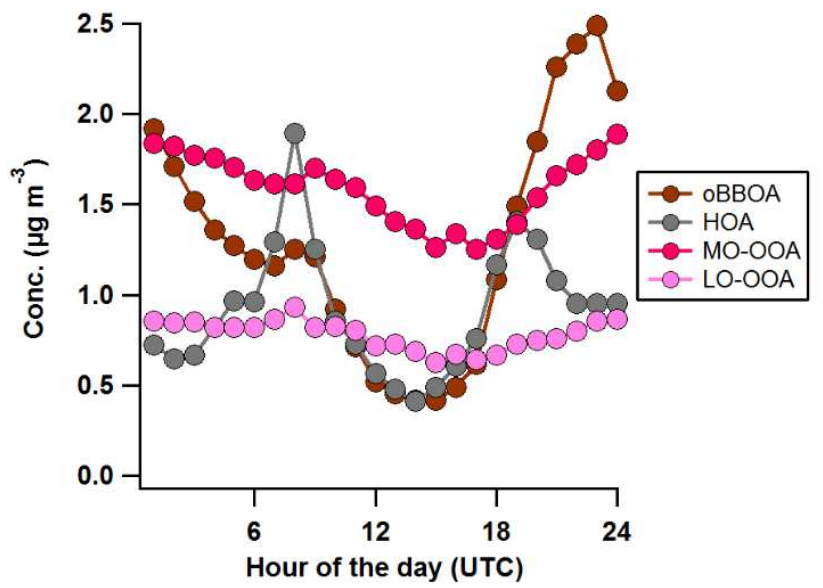

b)

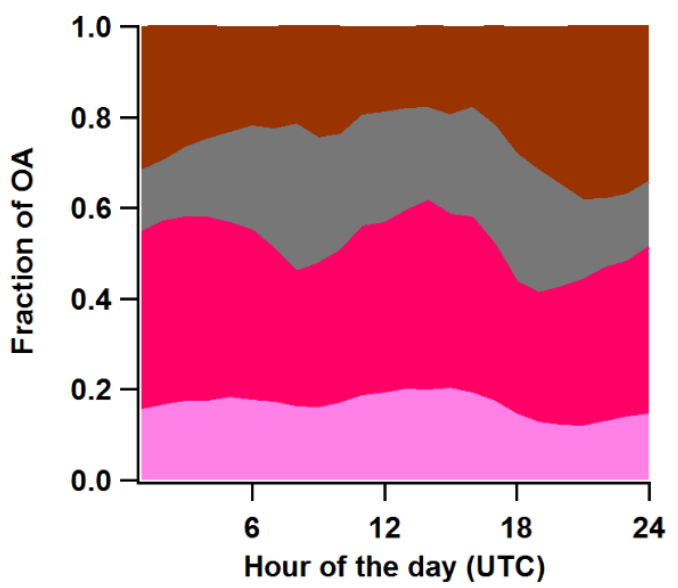

941

942

943

944

945

Figure 5. Daily profiles of PMF factors by (a) concentration and (b) contribution to OA (HOA: Hydrogen-like OA, oBBOA: oxidized biomass burning OA, MO-OOA: more oxidized oxygenated OA, LO-OOA: less oxidized - oxygenated OA). 
a) $\mathrm{HOA}$

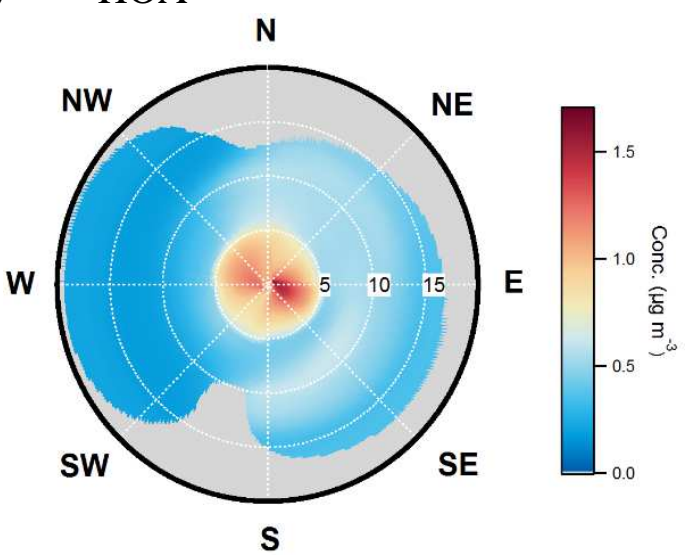

c) LO-OOA

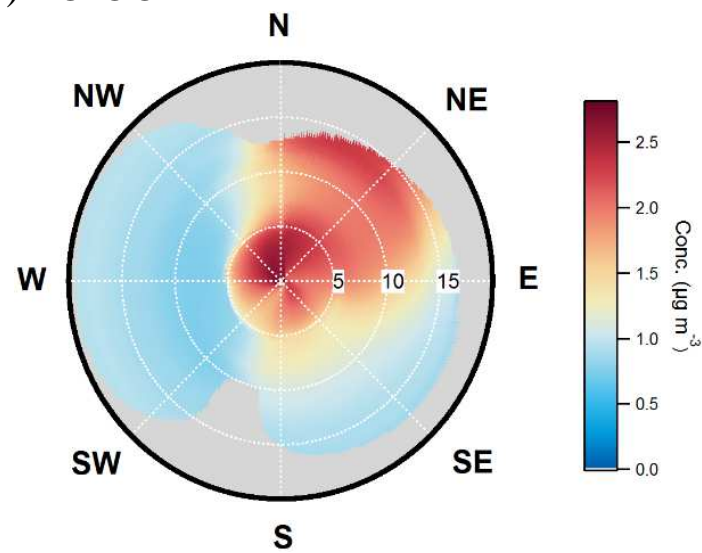

b) oBBOA

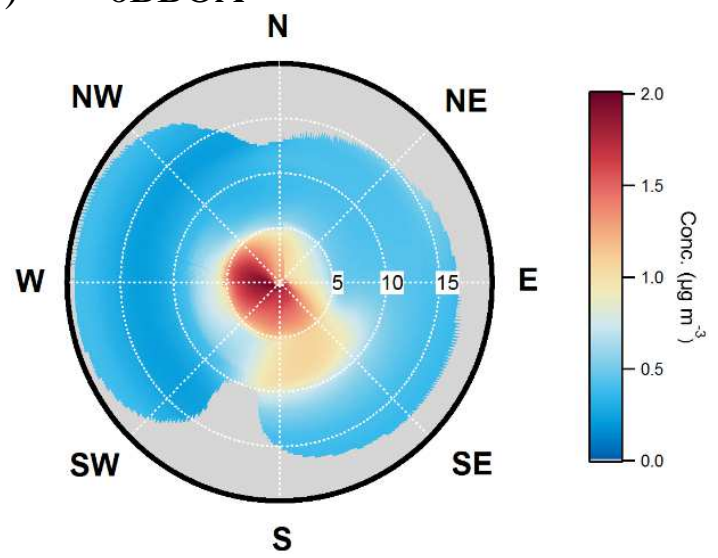

d) MO-OOA

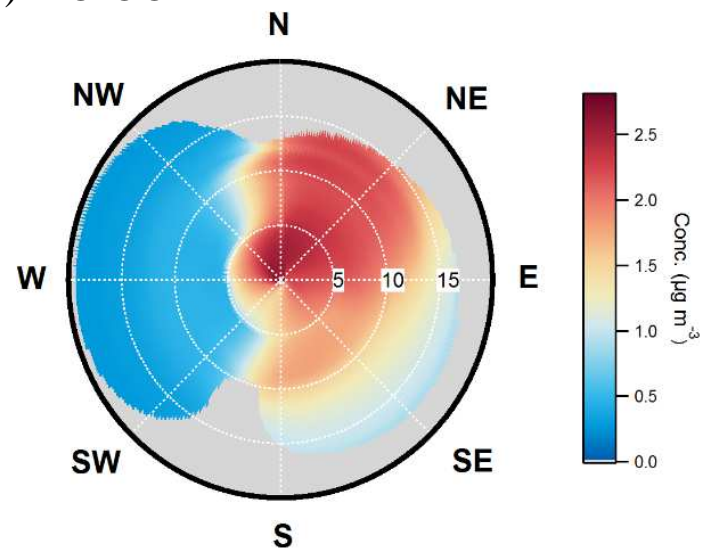

946 Figure 6. NWR plots for AMS PMF factors, colored by mass concentration (radius: wind speed 947 in $\mathrm{km} \mathrm{h}^{-1}$ ). HOA: Hydrogen-like OA, oBBOA: oxidized biomass burning OA, MO-OOA: more 948 oxidized - oxygenated OA, LO-OOA: less oxidized - oxygenated OA. 

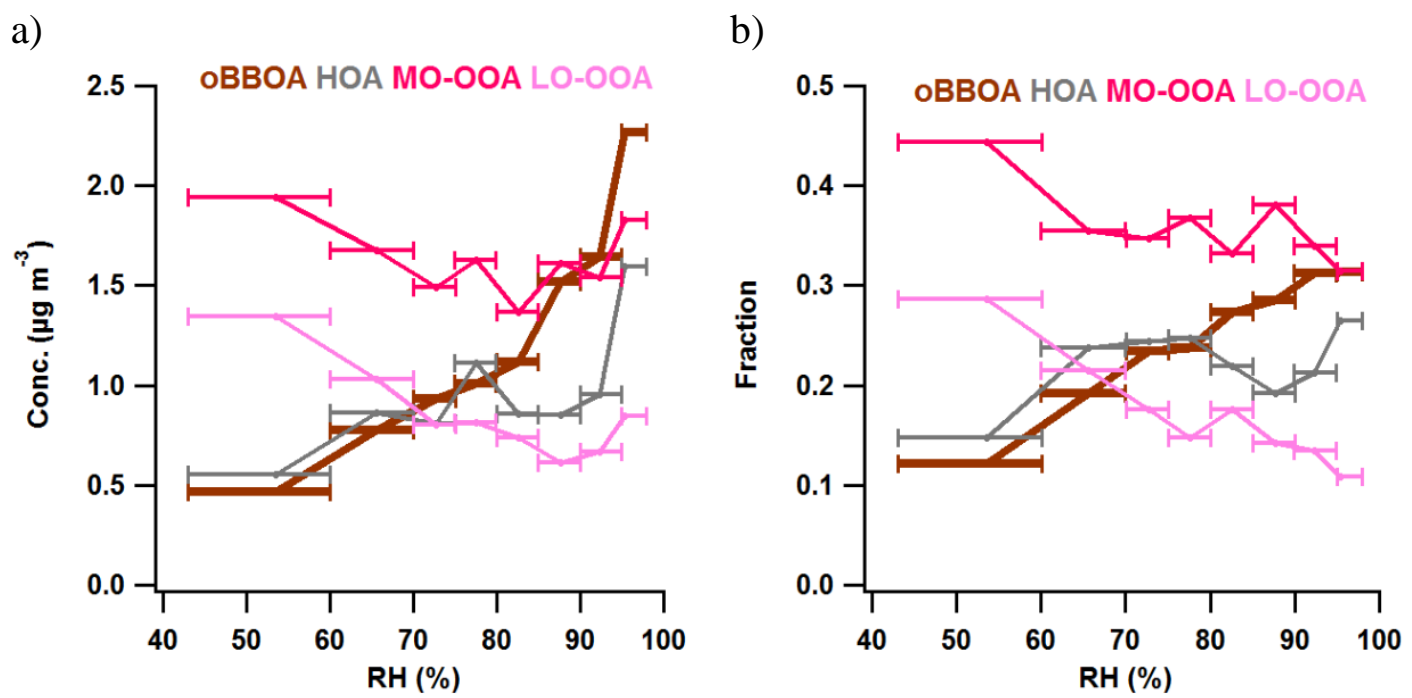

950 Figure 7. Averaged mass concentrations and relative contributions of PMF factors as a function 951 of RH bins (the width of the bins, represented by the horizontal bars, was chosen to increase the 952 representativeness of each interval, with $\mathrm{n} \geq 40$ ). HOA: Hydrogen-like OA, oBBOA: oxidized 953 biomass burning OA, MO-OOA: more oxidized - oxygenated OA, LO-OOA: less oxidized 954 oxygenated OA.

955 

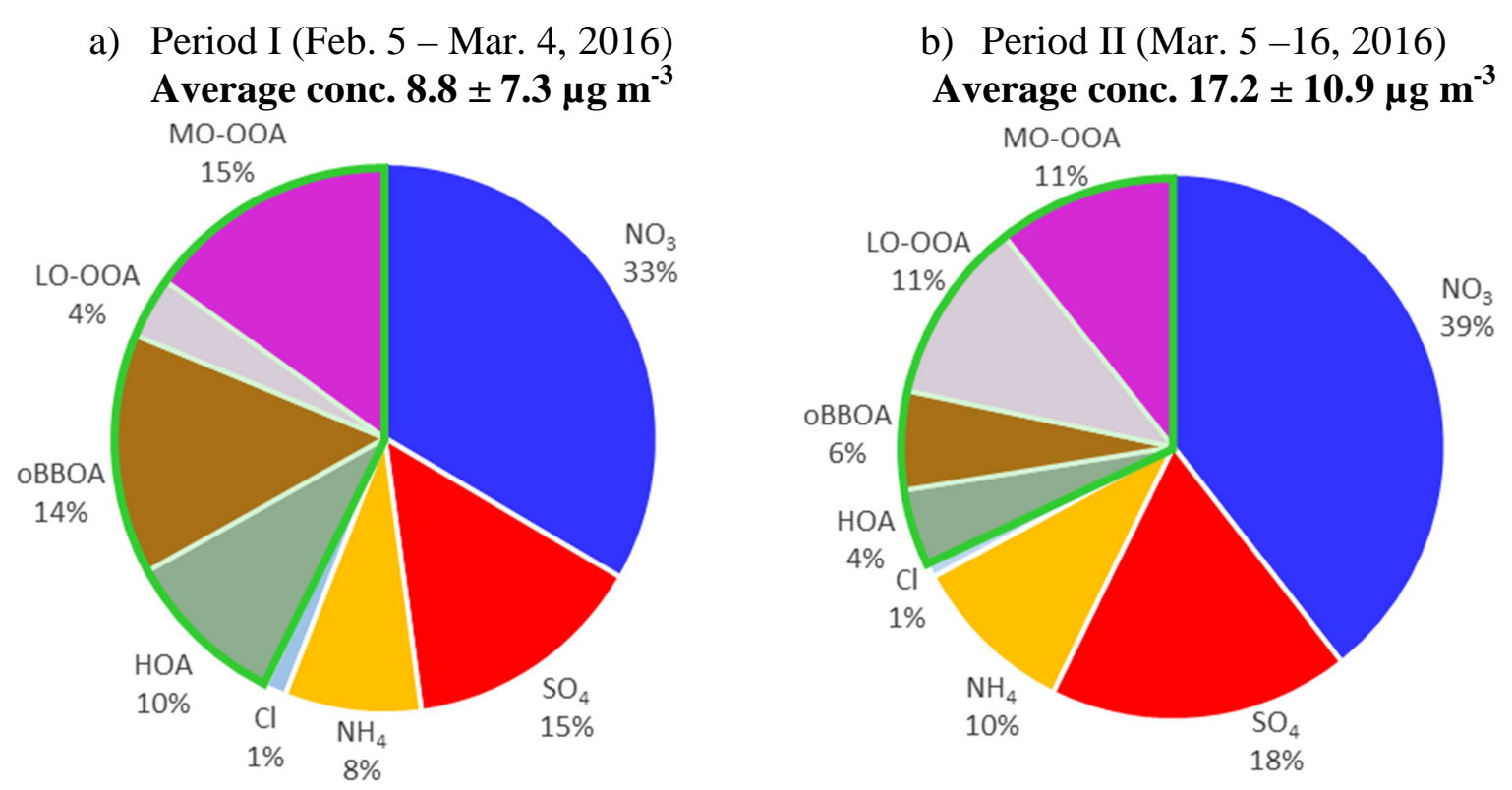

956 Figure 8. Average chemical composition of NR-PM 1 for (a) period I and (b) period II. The OA 957 fraction (highlighted in light green) is subdivided into its PMF factors.

958 
a)

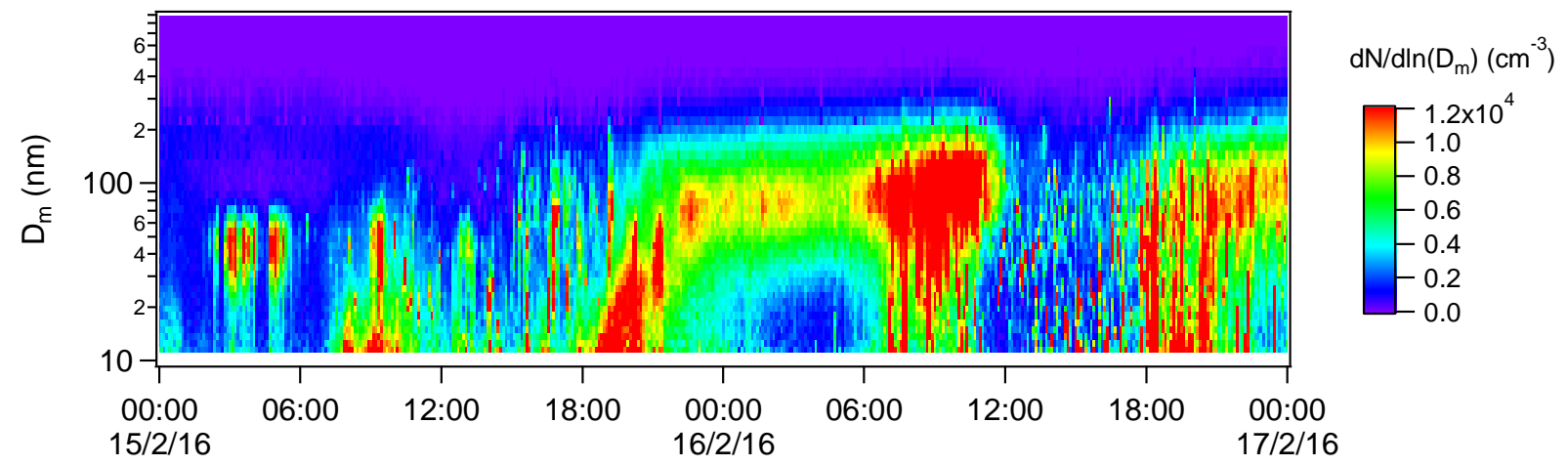

b)

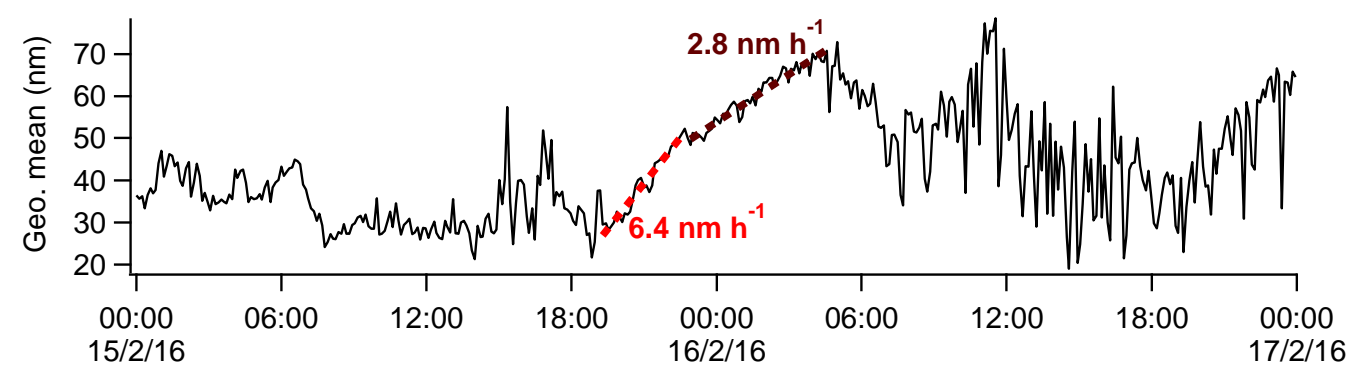

c)

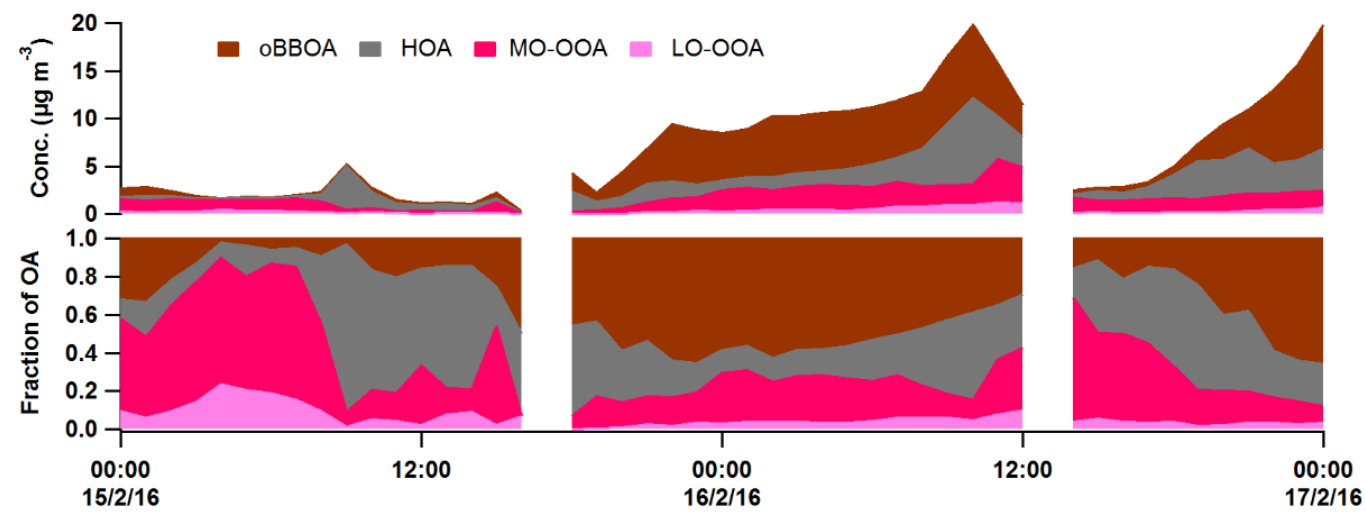

d)

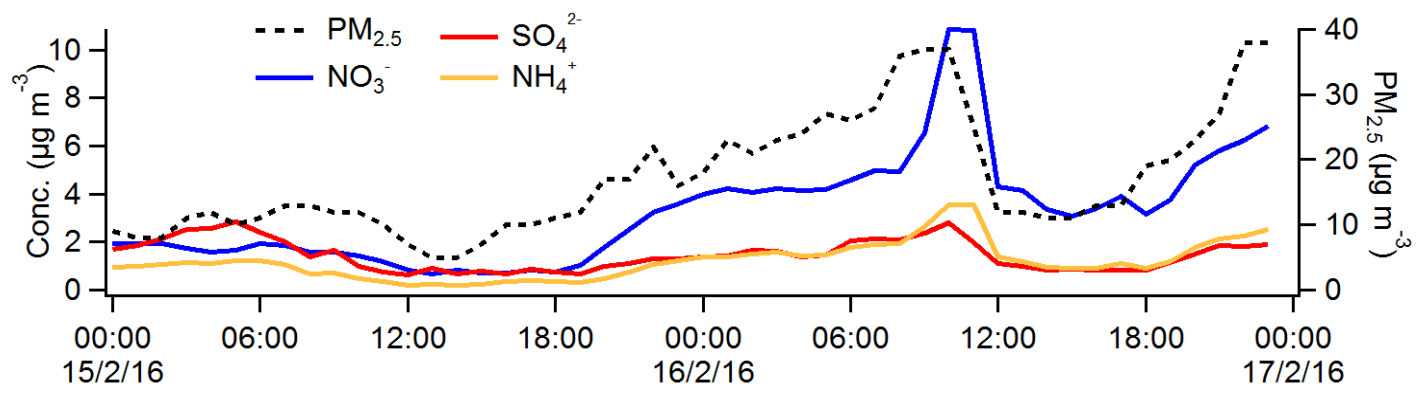

959 Figure 9. (a) Time series of the particle number size distribution (PNSD), (b) geometric mean

960 diameter, (c) PMF factors, (d) $\mathrm{PM}_{2.5}, \mathrm{NO}_{3}, \mathrm{SO}_{4}, \mathrm{NH}_{4}, \mathrm{BC}$ mass concentrations for the Feb.15-16, 9612016 NPF-like event 
Table 1. Summary of growth rates (g) recorded during NPF or NPF-like events at urban or polluted sites

\begin{tabular}{|c|c|c|c|c|c|}
\hline Reference & $\begin{array}{c}\text { Mean } \mathrm{g} \\
\left(\text { nm hour }^{-1}\right)\end{array}$ & $\begin{array}{l}\text { Range of g } \\
\left(\mathrm{nm} \text { hour }^{-1}\right)\end{array}$ & Size range $(\mathrm{nm})$ & Site & Measurement period \\
\hline This study & $\begin{array}{l}\text { (1) } 5.1 \\
\left(6.2^{\mathrm{a}-2.8^{\mathrm{b}}}\right) \\
\text { (2) } 5.1 \\
\text { (3) } 6.4 \\
\text { (4) } 6.3\end{array}$ & $2.8-6.4$ & $\begin{array}{l}\text { (1) } 30-70 \\
\text { (2) } 30-60 \\
\text { (3) } 20-80 \\
\text { (4) } 20-50\end{array}$ & Douai, France & $\begin{array}{l}\text { (1) } 15-16 / 02 / 16 \\
\text { (2) } 23-24 / 02 / 16 \\
\text { (3) } 04-05 / 03 / 16 \\
\text { (4) } 04-05 / 04 / 16\end{array}$ \\
\hline Fiedler et al. (2005) & $\begin{array}{l}7.7 \\
9.0\end{array}$ & $\begin{array}{l}1.3-12 \\
2.1-23\end{array}$ & $\begin{array}{l}1.3 \\
3-25 \\
\end{array}$ & Heidelberg, Germany & Feb.-Apr. '04 \\
\hline Stolzenburg et al. (2005) & 9.3 & $2.9-22$ & $10-90$ & Atlanta, United States & Jul.-Aug. '02 \\
\hline Hamed et al. (2007) & 7 & $2.9-23$ & & Po Valley, Italy & $\begin{array}{l}\text { Mar. '02 - } \\
\text { Mar. '05 }\end{array}$ \\
\hline Wu et al. (2007) & & $0.1-11$ & & Beijing, China & $\begin{array}{l}\text { Mar. '04 - } \\
\text { Feb. '05 }\end{array}$ \\
\hline Iida et al. (2008) & 18 & $6-40$ & $3.7-25$ & Tecamac, Mexico & Mar. '06 \\
\hline Cheung et al. (2011) & 4.6 & $1.8-7.8$ & & Brisbane, Australia & Jan.-Dec. '09 \\
\hline Man et al. (2015) & & 2.4-39 & & Hong Kong, China & $\begin{array}{l}\text { Mar.-Apr. and } \\
\text { Nov.-Dec. '11 }\end{array}$ \\
\hline Salimi et al. (2017) & & $\begin{array}{l}0.015-13^{c} \\
0.25-11.5^{d}\end{array}$ & & Brisbane Metropolitan Area, Australia & $\begin{array}{l}\text { Oct. '10 - } \\
\text { Aug.' } 12\end{array}$ \\
\hline
\end{tabular}


11

AMS measurements and source apportionment

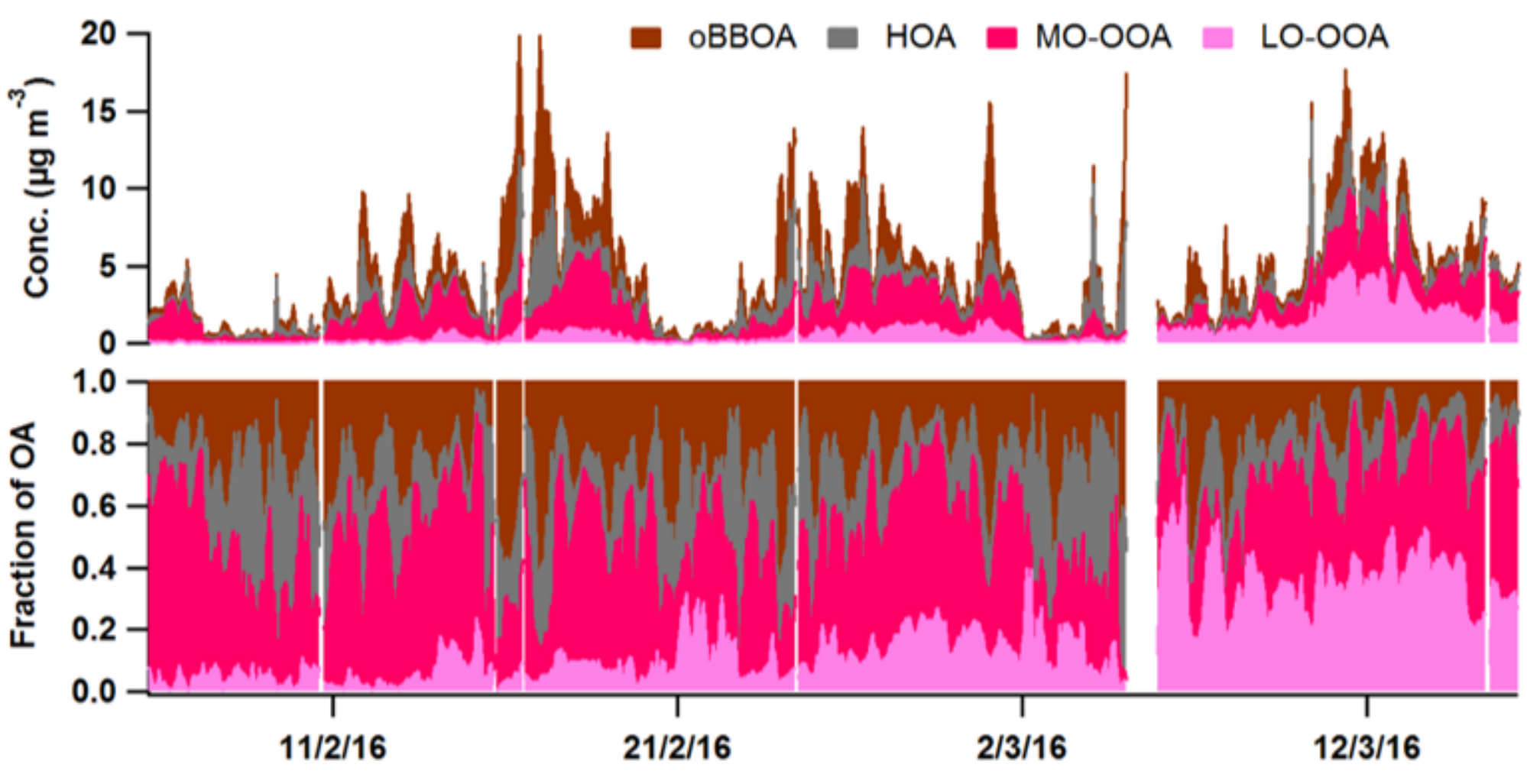

Identification of local vs. regional sources

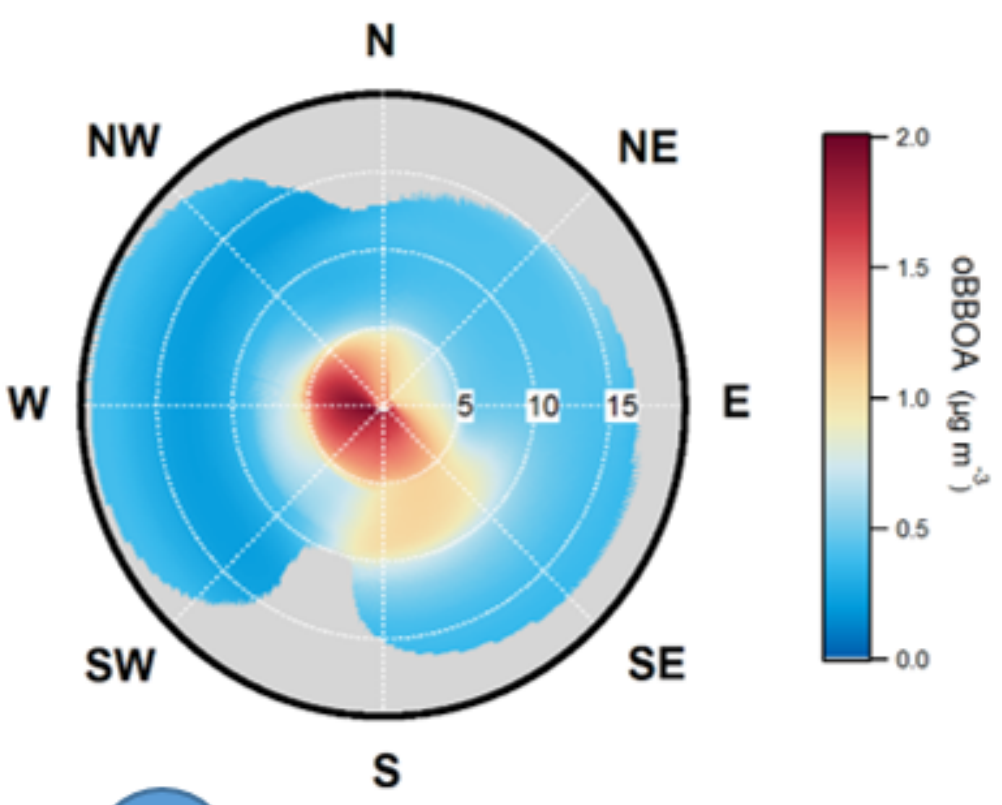

3

Analysis of specific periods / events

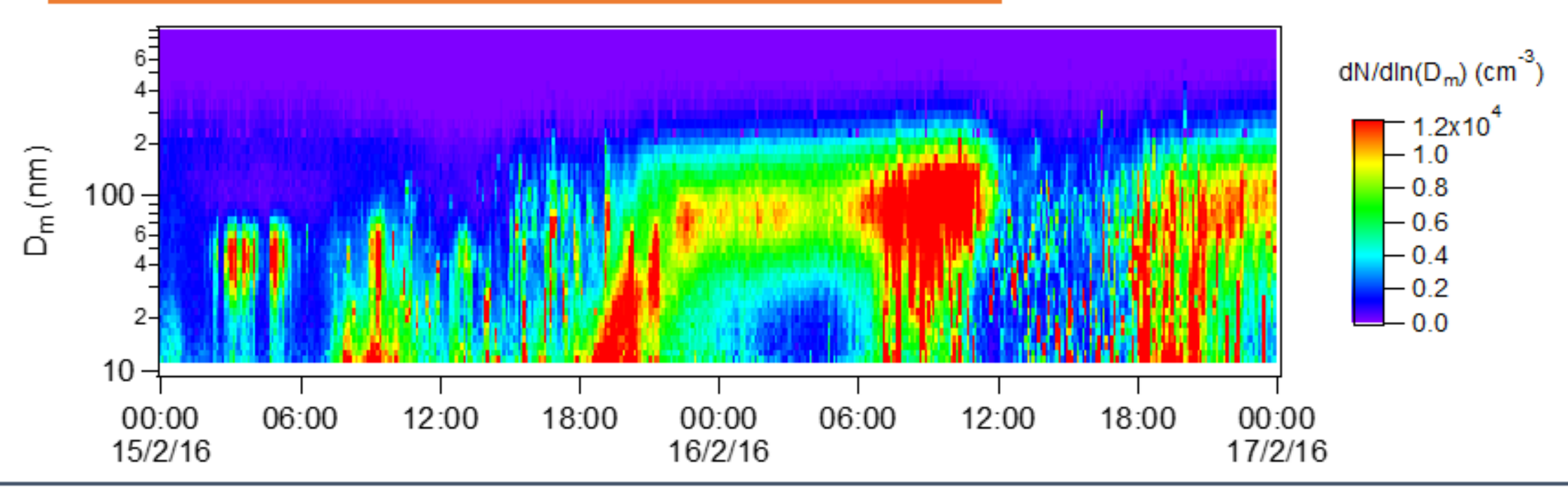

